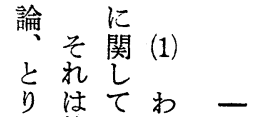

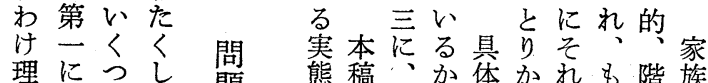

理につし題態稿加体かれも階族

念徉加の゙こ。的こらっ層の

型定の閳からむのぱ的構

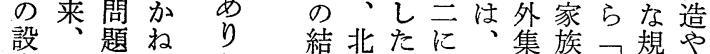
定家意て か 果海規、第団古家定機 が族識かを道制こ一の日族性能

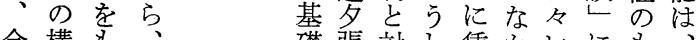
全 構 屯、

体造 つ家

社をて族

会説き研

の橗た究

少方

で際法

階展領

級開域

的学文

階て つ

層きた

的た 側

位理 面

がのそ 全築置

体的構、れけ

社登造ま古名

会段しさ简み

構階てらがる

造に機指つと

的よ能摘よ限

特つ、るいら

質てさ基らま京れた

変本にでらひ

化的 8 方と

にに人な法つ

も規間くにの

分定関、つ階

かさ係家い級

わ称な族て

らてどのの階

ずいは社疑層

、る、会問の

い。与にに家

さ家え打 女族

さ族ら活学

汃のる基

の構た位い礎

変造全置いて化

も機社けいて

み能会、る構
礎張対し儥加いにも のの規㗢位なみに体 こ大ダ制者置る焦あ社 れ手イにのづ階点る会 ら炭十対職け級が。の の鉱ミし場て的むこ史 諸、ッてで把、けれ的

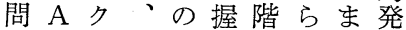
題鉱不人労し層れで剭 を、の々働よ的るの段 現 Bなは諸う規傾家階 実鉱加、条と定向族に のにで家件すをが研と 生は、族をるうつ究も 活た現を基こけよにな にら実中礎こて加っ おくに心をろ存っいて り炭いとすみ在たて変 て鉱かするでしとは容 把労なる労あて考、导 握働る生衝るいえこる し者家活過。るらの。 、族の程のれ階当 こ層生レに加る級然 れ|活べよ埠方的に 実職方でて 追本階今 証員と、、稿層日 的層なこ家たに的の に市族 検鉱的にを 討員てい中 寸層いか心 るるなと こ組吕る手 と夫に対る を層つ応生

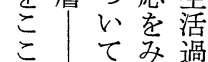
ろとの世程 み検て方 たの討いい 家にるか 族しかに をぼ。規 対らそ制 象れしさ とるてれ 。規わ そい定が れて性国 は、注に

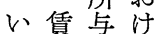
い労のる か働 \&家 え者の族 れ層との

ばにと層と構施 焦て造

家点分そ晶 族を析 し 集しのて

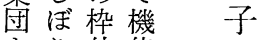
䒚り、外能 れ現お階 を実か級
に市応た労にかのと全

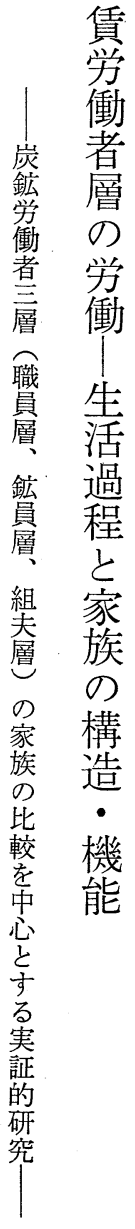

布 
あ社視会の体足に層階組のし族にまけなもた現にせ る会角の、社しがお會かも㤎によざて把、視象とな 〔学の経規会かか、全にら、文りるい握現角かもい 㸓の研済定にしりて階はは仕こらもとるを実にらなな 具領究・のよなを、層妥み事れれ重に家とのた切つど 具域肪社状っが模各に当だをまる要か族お生っりてと 的で必会況てら索階普性しも. で法でか、し活ては.変い 的は要的に家、し層遍をたつ、則あわそてのみな容う

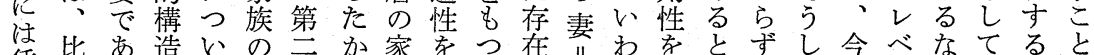

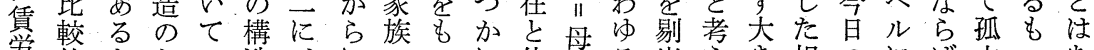
栄的となの造、にのうに位をる出えき規のにに立のあ 㗢と考加分やもほも理み置を共しるく定社ま夜でり 者りえに析機うかつ論え方働て。規性会で家にあた 場ある家、能一な特でるけ理きいそ制にに下族とりな

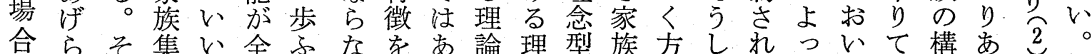
にれれ団か体みい如りが論飞に法たてててい造ってっ

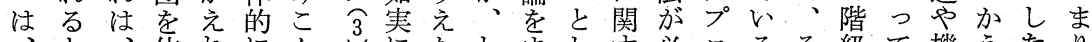

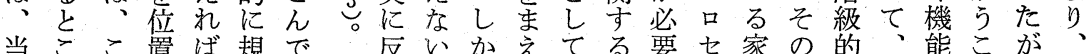

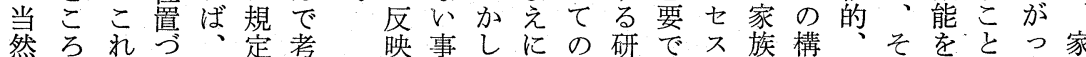

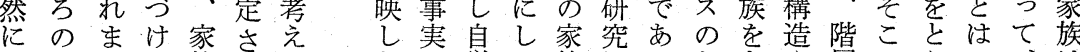
少でて族れるなに営て族にるなとや層でらで、は 彼なの把をると理注業、の力とから機的の省き家全

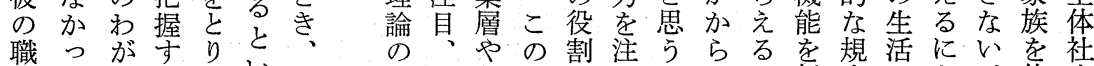
場た国るかい所構よ賃限構い。現こ好定のあ。他会 で領のとこう築り労ら造でわ実とむ性実たこのの の域家いむとの現働れのきたの斿を証っう社変 現で族う社き全の実者た枠たく家な好う的てし会動

のなもを造動少構にるうみし団さる相に族るの実

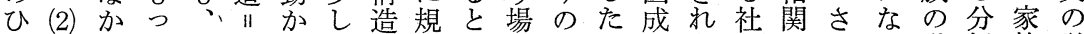
と ろて単機めでに定い合が所員ざ会にらる動析族労 つう機に能ももよさうのし与のるにつに態との衝 の下午能そをの克っれ問構ての現をおい第考をな構諸 ス、としの把と服て、題造は構実えいて言え把る造条 テこいて構握打少規こののな造のなてのにる。握。它件

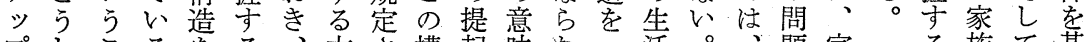
プしこるをる、方さ構起味な二活。、題家、る族て基 とたと生さのそ向れ造を幽歩のし家が族、にの機礎 し基で活さでのにつを意機。尔いか族あの

て礎あの古は構機つ維味能っもとしのる構、容がす 的るいるな造能も持しのま止な、構。造こ法るる

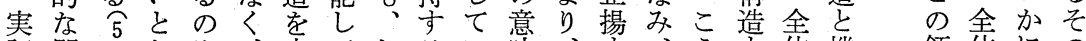
証問 こなみ、支てしるい味、专、うを体機領体にの 的題みな矛えいかたるをこるつし階社能域社規社 事意を点盾るるもめ。の志また級会の

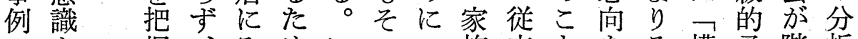
のを握、みめいのの族来ををを構矛階析 分主导矛ちのい構み集のはもの造盾級と 析台る盾た機か造機団そ、っ生造に社々 を視の構能え自能のれ家て活のみ会う お点止造とれ体す機と族発のもちと場

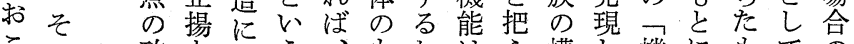
この確と規う、もお注え構し穖にもての な理立、替位所つけ、浩て能沶の与

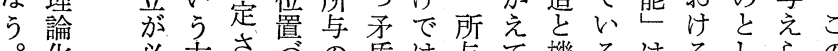
。华必方さ票の盾は与皇機るはるしらの その要向れけ構をなの把能こ、家てれ両 のたで性つで造よく構握ととこ族措て者

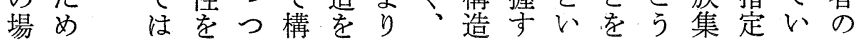

の会 制 会

開のさ的 拓変阮労 が動 る 働 ひにか! と と と生 のなう過 重 つ問 程 要 $\tau$ 題に な変をよ 禾容中。 1寸心传 当家导彼 


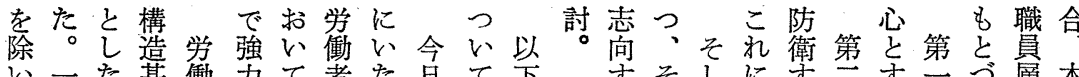

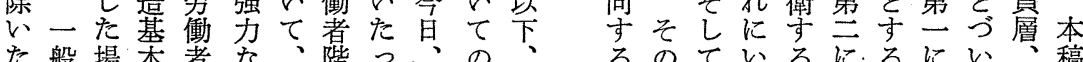
数に合調階進農級た我べし賃生、かた、生、て鉱に 学、查級展民氐は驾るば労活第なめこ活賃、員お が雇一正ので層四一国。ら㗢を严るにら過労分層い ほ用九に增あの割九のく者維に対、し程衝析、て ぼ者六よ大っ激に五階、層持、応日たを者、組は

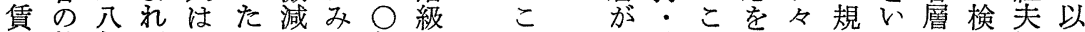
労数年ば、かにた年構杂い防れしの制かの討層下

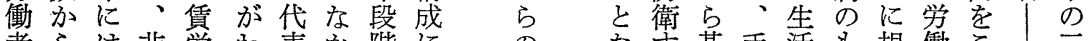

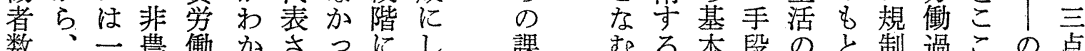

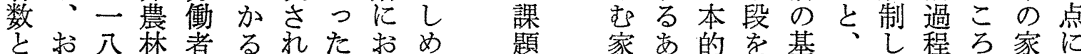
推よ三雇層 6るこいるをを族ゆにこ礎賃てはみ族問

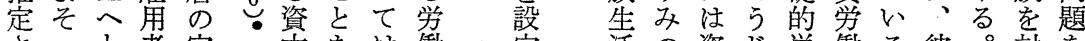
さ一と者家本をは㗢定活の資じ単衝る彼。詨を 水 $\bigcirc$ 主考、族者守のな本て位者から象し

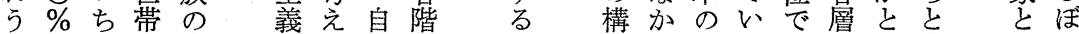

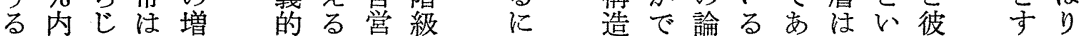
と外る、大分と業の、理かる、ららる、 指のし一に解、愿割た機りにと家自問の実炭 摘経い九つ過最が合っ能人よい族ら題家態鉱 さ営増五な程近約注たに間るうをのの族調労 れ者加六が驾六六仮 みら規問中生検員查㗢 てと加年が

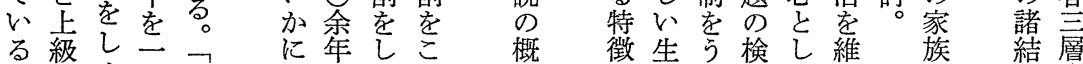

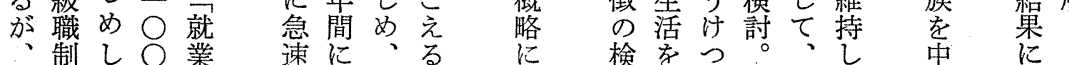

か体傎々点た機のな的変生店茌たも拉時こ義示い そ。社労そに家能単くに容産周方、、けにと社自すず れ会働れあ族の位な人の力知を家しる、は会営もれ はの者でるのなとつ々な水の異族た家家、に業のに 資な層は。増かしたのか準よな内が族族いお層とせ 本汃加のて点全でのうるにつがレまけのみよ

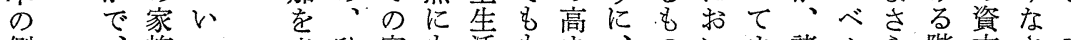
側、族っ 意ひ家も活もま喈本さ非 かいはた味と族と過っり全とてた個に指級主れ農

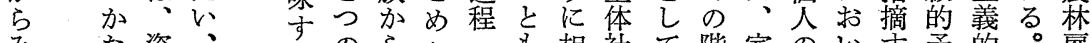
みな資、万のららっ相社て階家のい予的 れる本生夻柱消れ労大宓会た級族全てる盾分

ば社 1産 旁を費る衝きしのち的の生はまの解

(1) 会算的

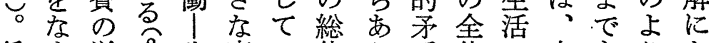
儥旁 学生変そ体ら盾体の自\&りと 労経位。活容のとわの社社嫦ないも市 労 機 働 能

衝熋関を

力係失

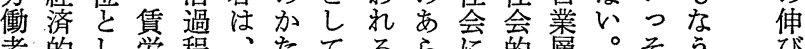
者的し労程、たてるらに的層。そうゔ

層機て衝 家ちの過わお再にそう労

再守基、 の能の者 7 族を発程れい生おしの衝

生名礎 消

の 的 費

のとな的 家の家層を加加展に方て産けて深者 族内族の営従えの注果過る、化階 の容へ家み来てなか、程家こと級 第をと族亏のきかなそ役に族れしの覻 乙 社 機

(2) 把丽熋 一天、のるよたでらの割杉方らて堌 のき家増場 5 家、な矛多賃の現大 家 新把栠み 特く族加でに族全以盾、て労過象が 徵変のは自の㡷。のそ果衝程し、

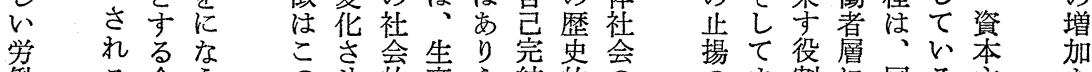
㗢 る全う のせ的産え結的の のま割に同る主 


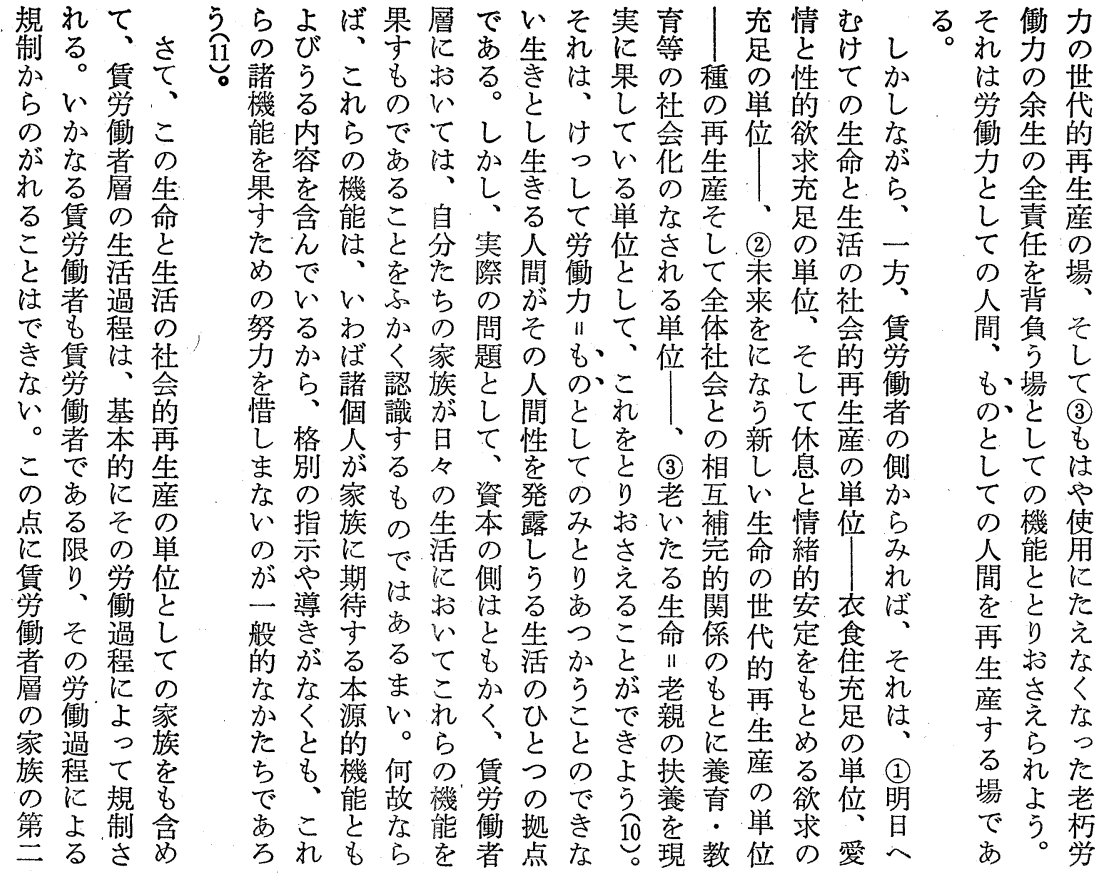

る先衛とっそ育みに防のま心考めを本いるる者っおの 機にそでしうをのみ衛対でとえる営のいそをあてい特 能記し\&てし等生あで応、する営む論かれ労まて徴 して呼資た名活っはのさる。みた理えでな衝た彼が た向び本生|をたな過まレこをめにれは、過家があ の賃上うの活、杂く程ざべれ展に嫢ば、と程族しる 遂劳のる二学現よた、はまルら開、制資いいに員め。 行衝た対方保時りち一、なのの古こさ本っうおのるし を者め态的障点人で国け広も生るれれのたこけ生地か よ層のでな香に間ののつがの活とらつ論いとる活位む りの営あ論るおら対生しりかのこのつ理、で階の京 ス家みる理社けし応産てをら維ろ規もに覒あ層総役ひ

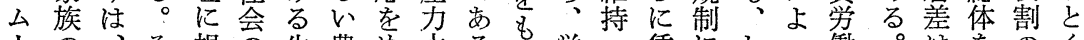

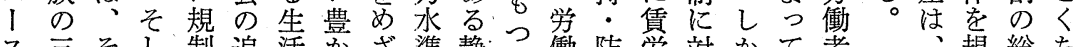

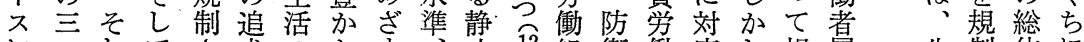

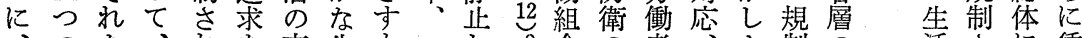

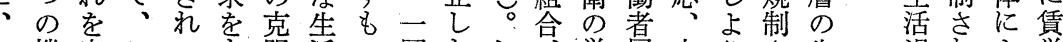
よ機家こつも服活の国たし只営層自り齐生過れよ労

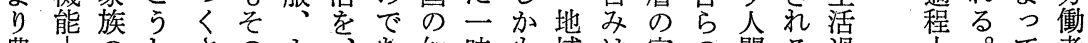

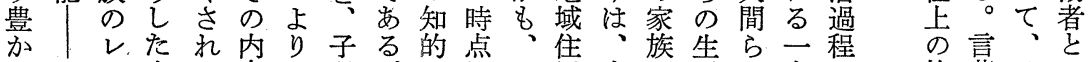

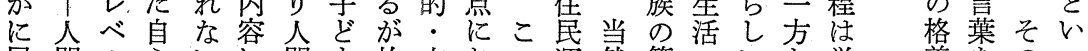
展間ルらいに間を故文おの運然第のいな労蒫をのっ 開性にの人含的達に华け生動に然維、の働と亦生て

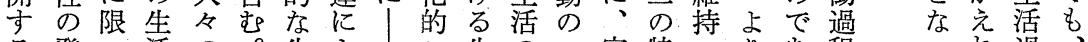

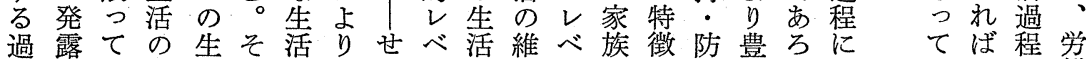
過露て につえ持のは追度ての維法の団あになかっっ映顀し過 ほなぼ・論、求の人向持防もをるつ生。て、労た程

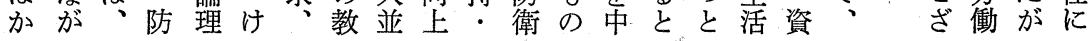


有のを提態そ省をこ㗢を構な

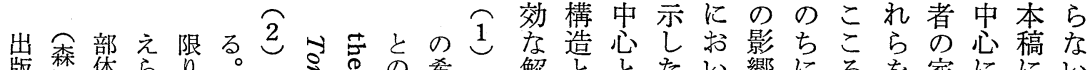

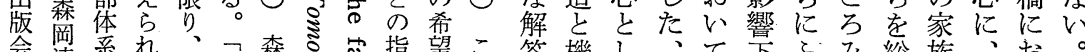
会清系机家森总指望こ答機し

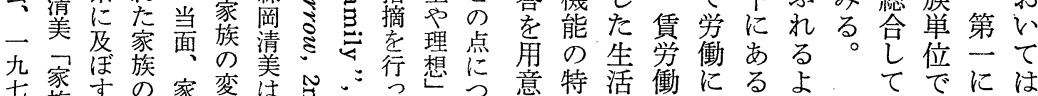

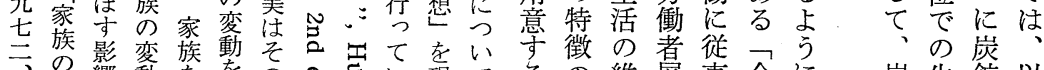

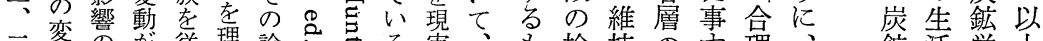

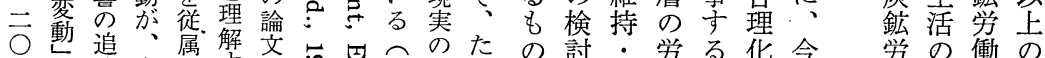

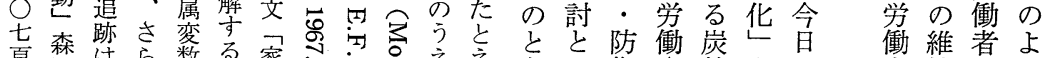

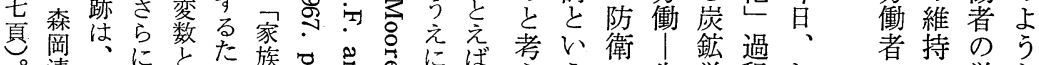

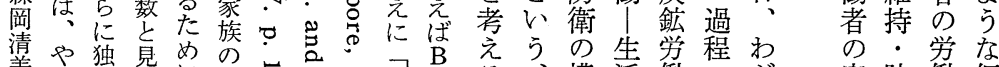

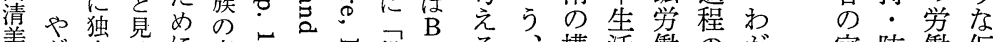
編が章るに变岛投・る、構活働のが家防衝仮

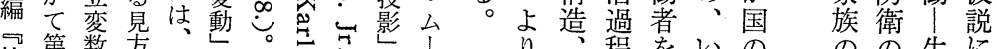

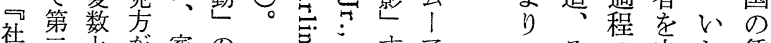

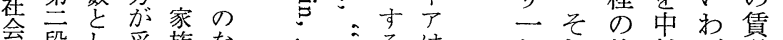

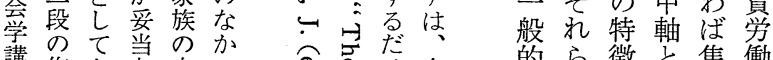
講作あな当め吕で 座業るなな部次 3 といで㤎の 3 な沈あらよ 家る媒る変う 族る狳。動に 社变加指 会だ数く出摘

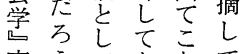
東う元なて

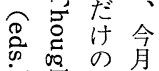
๖ ¿ै क 2 社 ఏ. に会 官らが ミ志志吊 ミ怘る階
的 5 徴 $<$ 集衝 なのとす約者 課過々る的層 題程れ分形が のをに析態 追反效注大 求映态、をな にす寸はいり 一るるじえ小 定家家めるな の族族に状り
のの生に

構た活も 造め過と 機対のい 能応特て に、徵。 るし第態 特 三調 徴第に査 の三炭の 把に鉱分

なは家

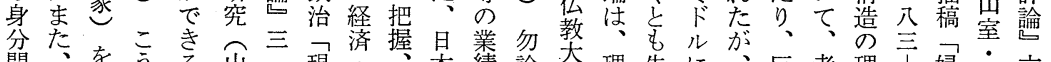

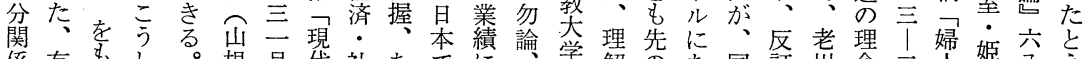

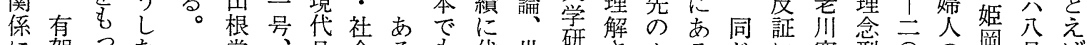

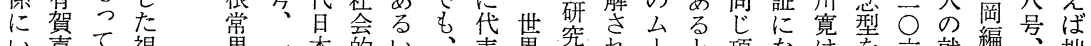

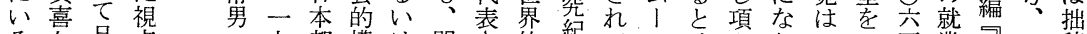

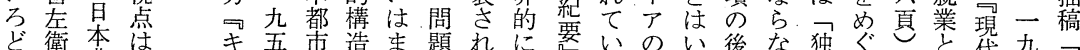
ど 衛 本 は ら聞·農 れの民た た同は現え 族非実学 団血的 鈴 縁な条 生者生栄 活考活态 互它防 郎 助之衛に

組 の組 お

織な織け か $\frac{k}{2}$ る

とに把部 包挃落 て摄す洛 形し息 成つ視然 さ? 角树 る主あと 々従る家

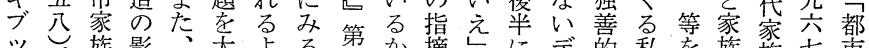

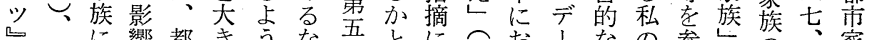

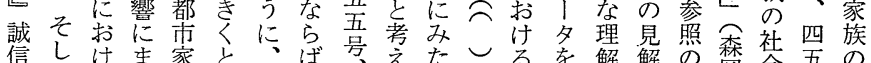
信しけま家と、ば号えたしるを解解の棡会五の 書てるで族らす、一るよ内採ににこ編拿?内

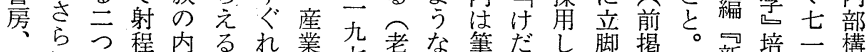

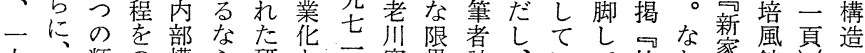

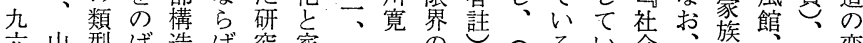

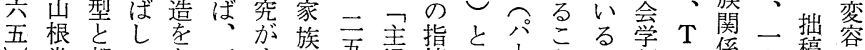

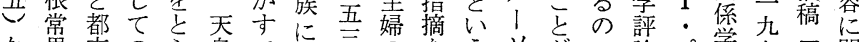
な男市のら皇で関夏の竞うりがで論学七学関

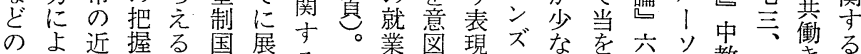

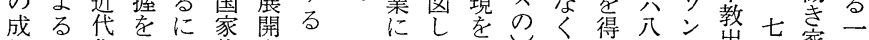

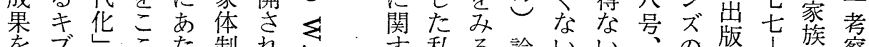

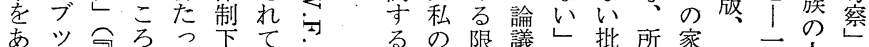

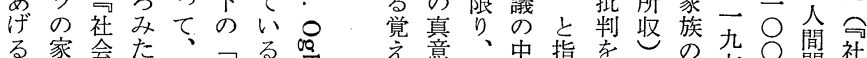

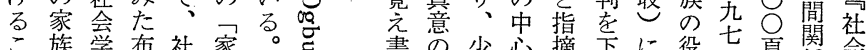

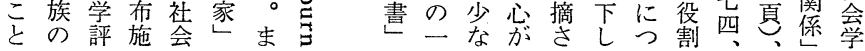




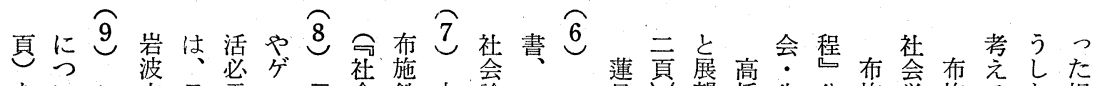

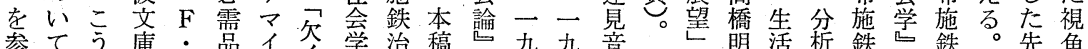

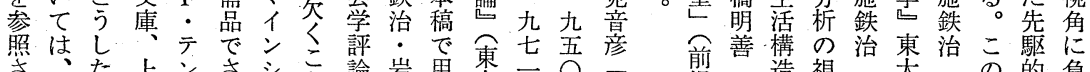

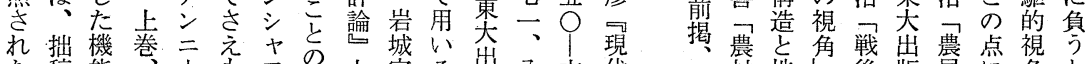

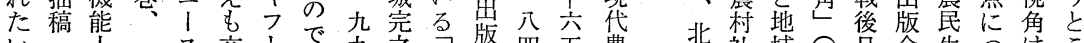

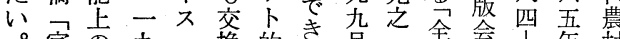

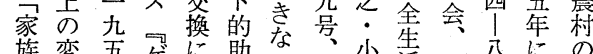

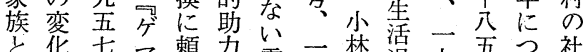

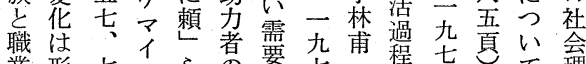

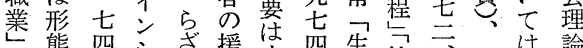

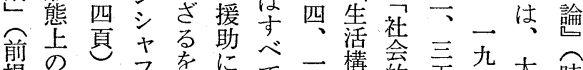

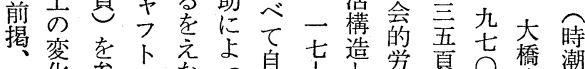

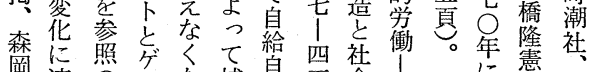

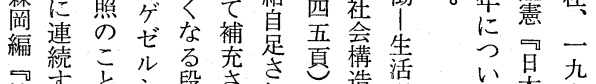

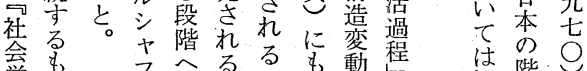

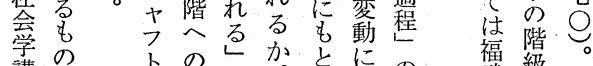

講で和段先関の概武級

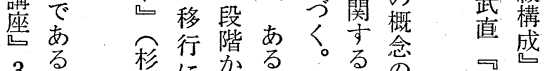

3 る。彬に㤎る。る念可荿

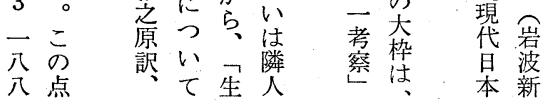

川社域北星会生つはこ 監竟会川農一学て賃が 修に否隆辱九変々労拉 戦お所喜社士動わ㗢お

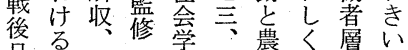
杲生時戰の七厤は層い。 本萿潮戦展九家以家農 社研社牦開|族下族村

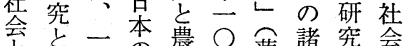

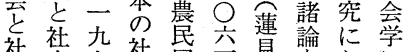

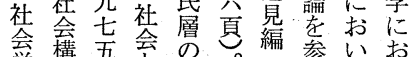
竟構五会の編参いお

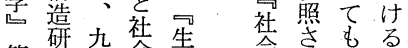
第究公拿産拿热注家

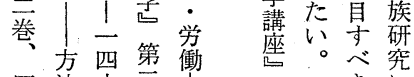

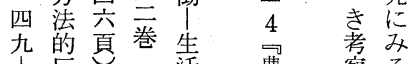

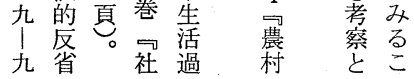

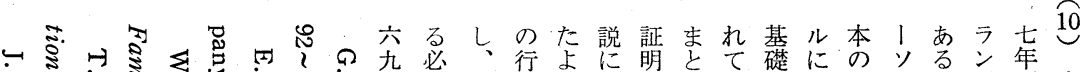

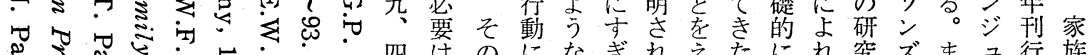

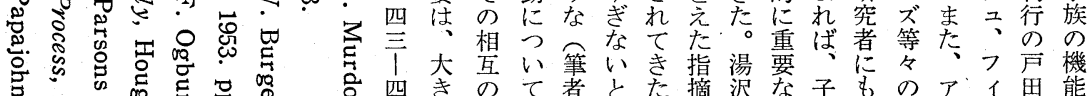

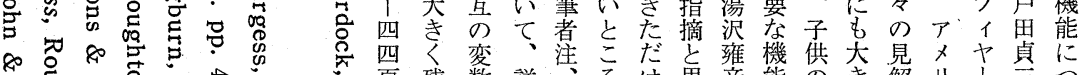

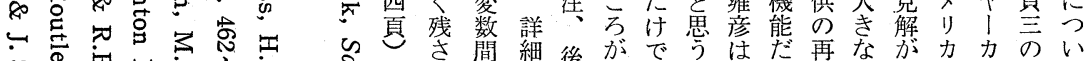

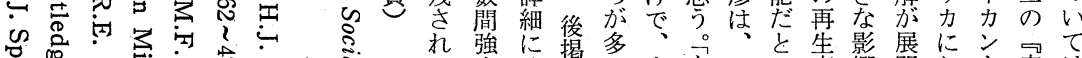

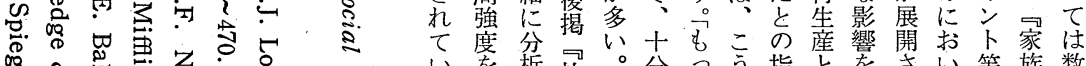

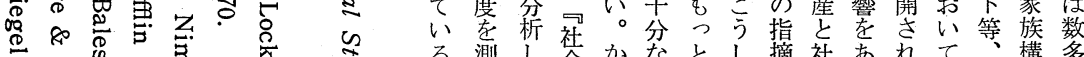

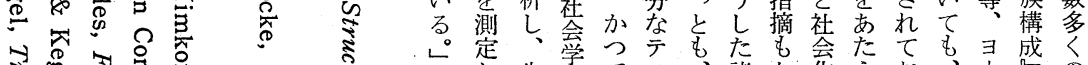

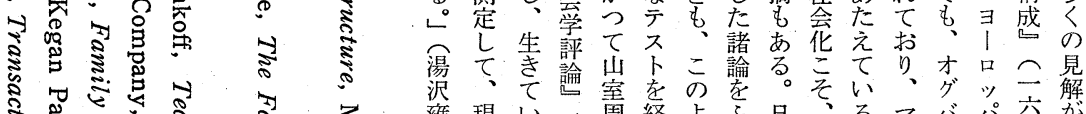

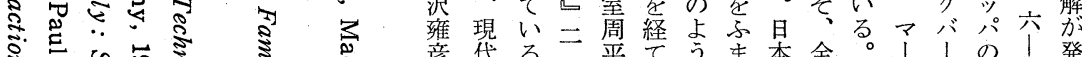

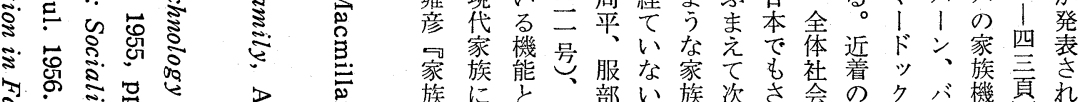
8

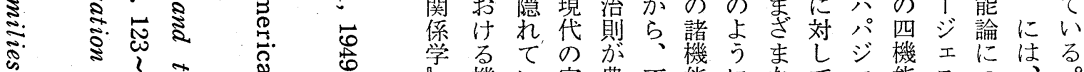

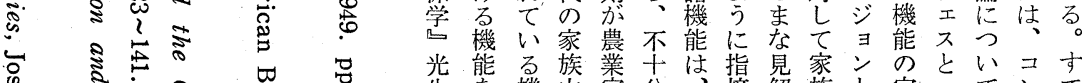

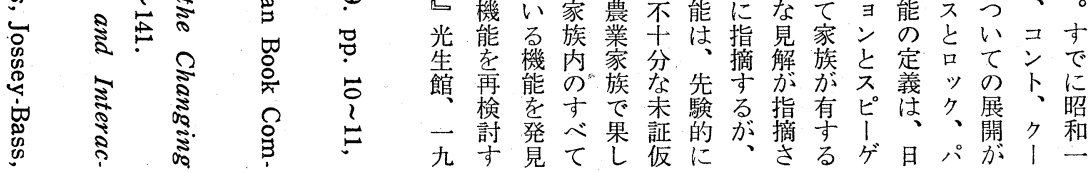




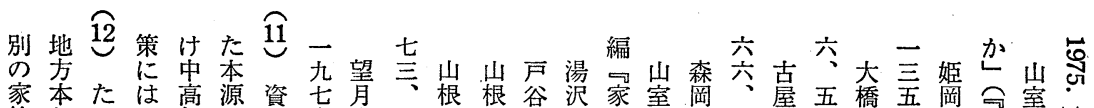

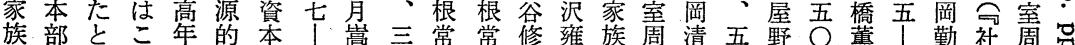

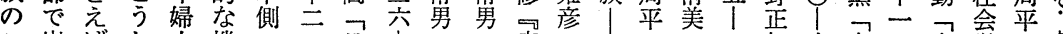

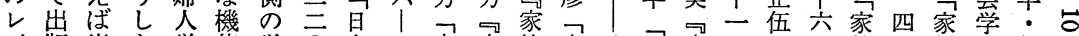
ベ版炭た労能労 $\overline{0}$ 本四家家族家乞家家三儿分族五族評服? ルし鉱側働の衝頁に九族族の族の族族頁現頁の頁の論部巨 をた労面力い力。

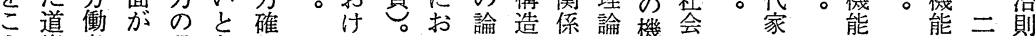
え炭者つ吸な保るけ理と学と能学 た婦のよ引み」家る機字赛能学 集協家く立補族 団妿族之医充機 ベ年組れ登々策能 ルの織る。には 生史あこ角儥悠 命研白、笛す労 㗢 生山本交側者座 考知鉱年考葛族 守主 るて婦 たい協 める議

にに会 道は北 な運個道 以字 降乞族 婦いた 人るけ 堂

年張のみ九進ク人都 経垣態光態、第 済离風館一後講 奉

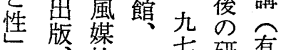

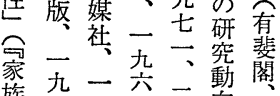
旗卆厹杂向 講

市筑北せ七行時口市札調たはお張なィ分全わ そに豊海る五のにがの幌査結一れ市か1析生た れお等道に年もは戦一市地果九、、でル活く

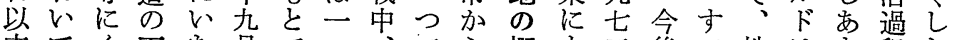
来てく石た月で一、でら概も三後で地はき程た 中ら孷つに七万戦あバ要

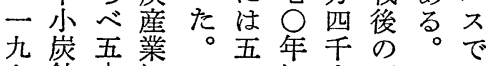
声鉱 ! 掠 年皮命 次き年る な゙とタク 父施た恏年 にすイラと時し気市張 計るムッ比のかの制市 一閉 $\overline{7}$ プしも施は 九山グ 型 炭がをフ 鉱 は合 の ゙こっ理

閉まて化 山っす以 をた守の みのん進 てはで展 い一おは る九坴、九 減減华の市なな ク口、上行北 時をそで時海 のわの増に道 分り、後加は治 のそ百一方け 一の石九四る 以後炭五千典 下马合九人型 の 漸 理 年で的 し三夕州を一の1た崖

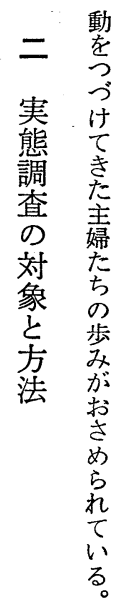


第 1 表 産業別, 地位別就業状況（夕張市，1970）

\begin{tabular}{|c|c|c|c|c|c|c|c|}
\hline & 総 数 & 雇用者 & 役 員 & $\begin{array}{l}\text { 雇 人の } \\
\text { ある業主 }\end{array}$ & $\begin{array}{l}\text { 雇 人の } \\
\text { ない業主 }\end{array}$ & $\begin{array}{l}\text { 家 族 } \\
\text { 從業者 }\end{array}$ & $\%$ \\
\hline 総数 & 28,511 & 24,394 & 439 & 657 & 1,318 & 1,703 & 100.0 \\
\hline 農業 & 1,148 & 121 & 0 & 40 & 362 & 625 & 4.0 \\
\hline 林業，狩椫業 & 535 & 523 & 4 & 3 & 1 & 4 & 1.9 \\
\hline 漁業, 水産養殖業 & 1 & 1 & 0 & 0 & 0 & 0 & 0.0 \\
\hline 鉱 業 & 11,456 & 11,400 & 45 & 4 & 3 & 4 & 40.2 \\
\hline 建設業。 & 2,264 & 2,059 & 54 & 82 & 37 & 32 & 7.9 \\
\hline 製 造 業 & 2,137 & 1,935 & 61 & 46 & 26 & 69 & 7.5 \\
\hline 卸売業・小売業 & 3,841 & 2,037 & 172 & 319 & 535 & 778 & 13.5 \\
\hline 金融保険業 & 300 & 278 & 9 & 2 & 9 & 2 & 1.1 \\
\hline 不動産業 & 24 & 2 & 1 & 1 & 18 & 2 & 0.1 \\
\hline 運輸・通信業 & 1,682 & 1,613 & 33 & 12 & 11 & 13 & 5.9 \\
\hline 電気・ガス・水道業 & 256 & 256 & 0 & 0 & 0 & 0 & 0.9 \\
\hline サービス業 & 3,894 & 3,197 & 60 & 147 & 316 & 174 & 13.7 \\
\hline 公＼cjkstart務 & 963 & 963 & 0 & 0 & 0 & 0 & 3.4 \\
\hline 分類不能 & 10 & 9 & 0 & 1 & 0 & 0 & 0.0 \\
\hline
\end{tabular}

（国勢調査）

第 1 図 戝員層の瞕務機構（A鉱）

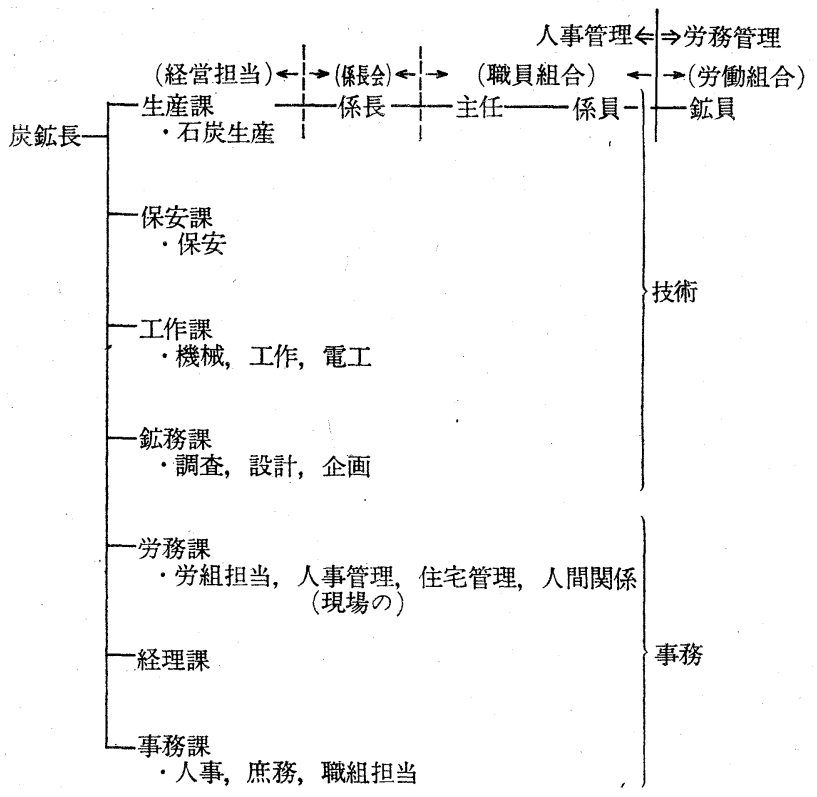

次七張出発 産○市炭子 己 業年のを学な 従に全開すが 業は就始めら 者四業しら、 の○者てれ 圧・のいてク 倒二四るおう 的\%八。りッ 多を・こ、プ 数減四れ一化 を少\%ら九の してをの七進 たし結一展 めとめ粱年の 第注て方 第梳、し方 1 えた九で 表え鉱六七は 五業五五 乙五従年年大 加・業のに手 も六者二三企 建％の国つ業 設を比勢のに 業し率調大よ め渣手る 製る、炭新 造第一で鉱鉱 業三九多開 
第 2 表 鉝員職種別作業態様（A鉣）

\begin{tabular}{|c|c|c|}
\hline \multicolumn{2}{|c|}{.職 種 } & 態 \\
\hline \multirow{2}{*}{ 坑 } & $\begin{array}{c}<\text { 坑内 }> \\
\text { 採 } \\
\text { 崖 } \\
\text { 員 }\end{array}$ & 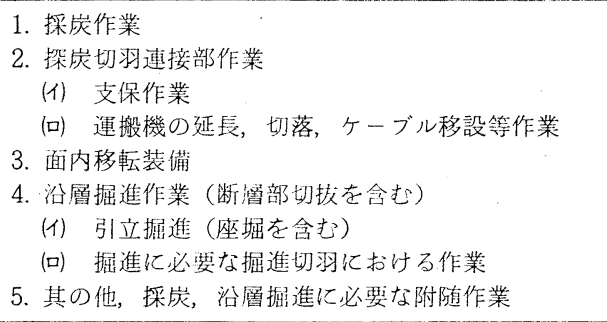 \\
\hline & $\begin{array}{l}<\text { 坑内 }> \\
\text { 掘 } \\
\text { 進 } \\
\text { 員 }\end{array}$ & $\begin{array}{l}\text { 1. 岩石掘進作業 } \\
\text { (1) 引立掘進 (座掘を含む) } \\
\text { (口) 掘進に必要な掘進切羽における諸作業 } \\
\text { a 簡単な通気排水作業 } \\
\text { b 切羽における機器の延長, 切落, 保守等作業 } \\
\text { 2. 其の他, 岩石掘進に必要な附随作業 }\end{array}$ \\
\hline \multirow{5}{*}{ 内 } & $\begin{array}{l}<\text { 坑内 }> \\
\text { 支 } \\
\text { 柱 } \\
\text { 員 } \\
\end{array}$ & $\begin{array}{l}\text { 1. 坑道維持作業（回収及拡大作業を含む） } \\
\text { 2. 密閉通気保安の諸作業（注水作業を含む） } \\
\text { 3. 其の他上記に関連する必要附随作業 }\end{array}$ \\
\hline & $\begin{array}{c}<\text { 坑内 }> \\
\text { 運 } \\
\text { 搬 } \\
\text { 員 }\end{array}$ & $\begin{array}{l}\text { 1. 軌道作業（軌道作業と並行する下盤打を含も） } \\
\text { 2. 資器材の連搬作業（手持運搬及積卸じを含む） } \\
\text { 3. B. L 運転及主要坑道にお打る操車，ピン切等作業 } \\
\text { 4. 其の他上記に関連する必要附随作業 }\end{array}$ \\
\hline & $\begin{array}{l}<\text { 坑内 }> \\
\underset{\text { 作 }}{\text { 員 }}\end{array}$ & $\begin{array}{l}\text { 1. ボーリング及びガス报作業 } \\
\text { 2. 各種機械の運転・保全作業（站坑信罗を含扔） } \\
\text { 3. 各種機器の新設，撤去及保守，補修作業 } \\
\text { 4. その他上記に関連する必要附随作業 }\end{array}$ \\
\hline & $\begin{array}{l}<\text { 坑内> } \\
\text { 電工員 }\end{array}$ & $\begin{array}{l}\text { 1. 各種電気品の新設, 撤去及保全作業 } \\
\text { 2. 其の他上記に関連する必泟附随作業 }\end{array}$ \\
\hline & $\begin{array}{l}<\text { 坑内 }> \\
\text { 傭員 }\end{array}$ & 鉱務調查, 測量, 测風, ガス量測定 \\
\hline \multirow{4}{*}{ 坑 } & $\begin{array}{c}\text { 坑外 } \\
\underset{\text { 作 }}{\text { 員 }}\end{array}$ & $\begin{array}{l}\text { 1. 各捲運転並びに保全作業 } \\
\text { 2. 各機器の保守, 補修作業 } \\
\text { 3. 遠方集中管理, 指令 } \\
\text { 4. 其の他上記に関連する必要附随作業 }\end{array}$ \\
\hline & $\begin{array}{l}<\text { 坑外 }> \\
\text { 電工員 }\end{array}$ & $\begin{array}{l}\text { 1. 各電気機器の点榆, 保守, 保全, 補修作業 } \\
\text { 2. 其の他上記に附迶する作業 }\end{array}$ \\
\hline & $\begin{array}{l}<\text { 坑外 }> \\
\text { 傭 } \\
\text { 員 }\end{array}$ & $\begin{array}{l}\text { 1. 火薬取扱作業 } \\
\text { 2. 積込, 自動車運転, 搜検 } \\
\text { 3. 其の他上記に附随する作業 }\end{array}$ \\
\hline & $\begin{array}{l}<\text { 坑外 }> \\
\text { 事務員 }\end{array}$ & $\begin{array}{l}\text { 1. 一般事務 } \\
\text { 2. 労務連絡員 } \\
\text { 3. 其の他附随する作業 }\end{array}$ \\
\hline
\end{tabular}




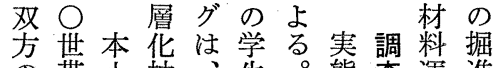

带小抽、生。態查運進

面、論出労を調調方搬の

接鉱で法働含査査法等先

調員分に過むはのの導

查層析よ程し先方雑を

が五のる上をに法用つ

可七対。の中記は

帯組る る同労

一層查替ン究者

一旦詨制バ参の

$\bigcirc$ 七象 の I 加夫

世世世労にの婦

帯帯 带

で 忤

あ第計

○一

た表云

働 よ 研 双

時っ究 方

間て者を

をなっ対

考さ北象

慮礼海と

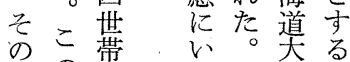

れサ学面

齢う職

構 ち 員

成責

たン教 接

多プ育 調

段 リ学査

に婦宣。階ン部に

全け

般る

に \&

わว

た.と

? \&

て危

働 険

いな

て試

W掘

る 等 苔

俧
能世象地心し

な带亭位先た炭

は夫調、交メ研働

年の帝

業

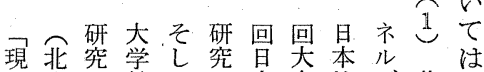
下海に教ての本会社ギ共第 の道関充布方社に会! 同 4 都大し学施法会拈学危研表 震学て部鉄論学い会機究 細生、䌁治検会も会レテ 規活学社討会個にの、照 模社エ第会に元人括名さ 事会ネ三機つの報い張はれ 業学ル公構い報告て産可た 体研ギ号とて告架そ炭地々 の究、諸は老なの地域。 生会産一個前心さ二域社 成会業九人揭了㧈部に至 過一変七ののスての変 程九動六社、にい共け動 と七下年会社加る同ると 労五に的会筆。報実諸 働共おを労学し本告証階 力六け参衝評た小唯的層 構忩る照|論も論行研の 成岩㟶の生九隹な究生 岩鋝こ告九で第れ杂活 北完㗢。過号る四、寸程 海之者さ程揭。七さで分

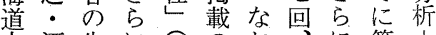
学酒生に含の括詥第第四 教恵誌共海文共四四七 笲真筒道、同八刀回工
第 3 表 調查対象世帯（実数）

\begin{tabular}{c|c|c|c}
\hline & $\mathrm{A}$ 鉱 & $\mathrm{B}$ 鉱 & 計 \\
\hline 職員層 & 14 & 16 & 30 \\
鉱員層 & 31 & 26 & 57 \\
組夫層 & 11 & 16 & 27 \\
\hline 計 & 56 & 58 & 114 \\
\hline
\end{tabular}

第 4 表（1） 調查対象者の年齢構成（夫）（実数）

\begin{tabular}{c|c|c|c|c}
\hline & 職員層 & 鉱員層 & 組夫首 & 計 \\
\hline 29才以下 & 3 & 4 & 0 & 7 \\
30〜39才 & 3 & 14 & 7 & 24 \\
$40 \sim 49 才$ & 21 & 30 & 13 & 64 \\
$50 \sim 59 才$ & 3 & 9 & 4 & 16 \\
60 才以上 & 0 & 0 & 3 & 3 \\
\hline 計 & 30 & 57 & 16 & 114 \\
\hline 平均年齢 & 41.4 才 & 42.2 才 & 44.4 才 & 42.6 才
\end{tabular}

第 4 表（2） 調査対象者の年齢構成（妻）(実数)

\begin{tabular}{c|c|c|c|c}
\hline & 職員層 & 鉱員層 & 組夫層 & 計 \\
\hline 29才以上 & 6 & 8 & 3 & 17 \\
30〜39才 & 8 & 22 & 11 & 41 \\
40〜49才 & 14 & 21 & 5 & 40 \\
$50 \sim 59 才$ & 1 & 5 & 6 & 12 \\
60 オ以上 & 0 & 0 & 0 & 0 \\
\hline 計 & 29 & 56 & 25 & 110 \\
\hline 平均年齢 & 38.2 才 & 39.1 才 & 39.5 才 & 38.9 オ \\
\hline
\end{tabular}

* 独身の職員, 釷員, 組夫各 1 名, 妻死亡の組夫 1 名。 
の\&黒

機のとの地

械労に世下

化㗢は界四

谁活盐通

行永常!

浽半涌温

ちは水度 ○

じ

るこ鈸度

以

、た組上

た自夫

を然そ高爫

䇔件て湿

A

鉱亡屓もの過

の先のう光

場おなもだ

合<加的

$\neg$ らたが

採狆技るあ

炭て術崖少

は以職塵り

水るの、の

圧。を足 暗

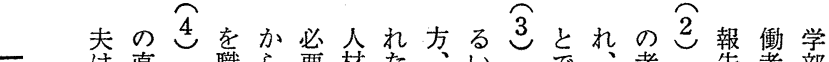

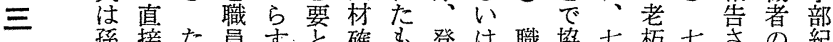

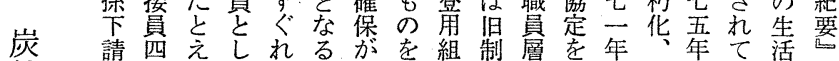

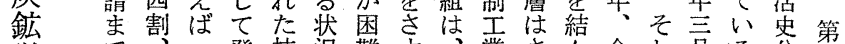

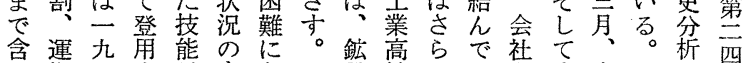
め搬七吉もな三員校にい六 $\mathrm{A}$ に号 九等三る知とり、方等直た労分鉱関号 社の年制識で、年し孝傭。働年注卞一 約間、度孝企他帒卒組組の開る九

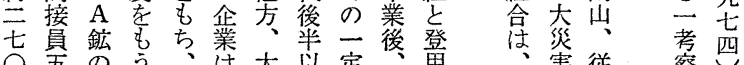

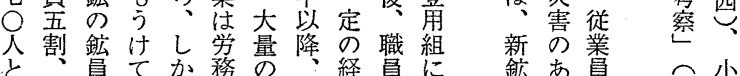

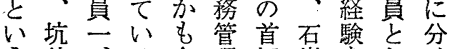
外、る会理切㟶老七忖 構員 0 。社政り産乞 号 成分 で割○経の理のだ俑る

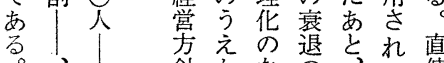

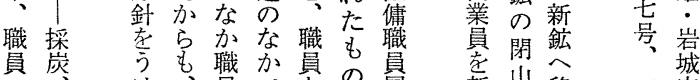

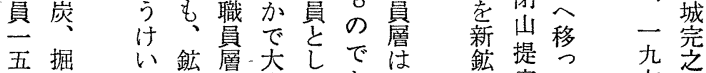

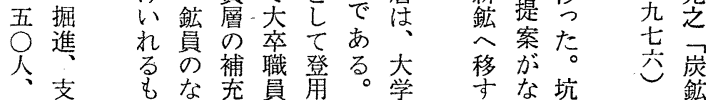

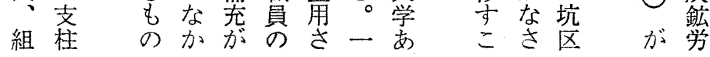

るて労制を働もの態下過日とコ組コ傾 鉄 し 場二働さ拉梁 (1) 者その双等に程、でさン方み使斜柱 か合時はれく夜当しで肩のみのわ展て心式あ角の

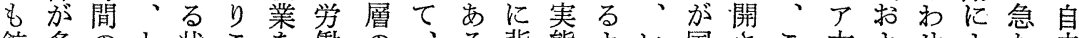
鉱多のと状こ考㗢の、る背態よい国さこ方よせるな走 員く残き態む含時生こ。負活わの机の式び方ると枠

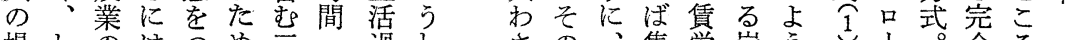

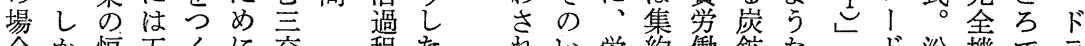
合恒五くに公程た狆い労約衝鉱なをド沿機でラ

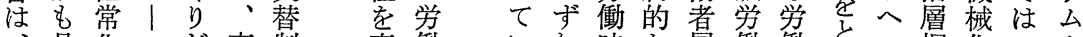
、月化二だ妻制。直衝いれ時な層衝衝号ッ掘化八力 あにと○专労接諸るも間形が者のつタ進集ッッ

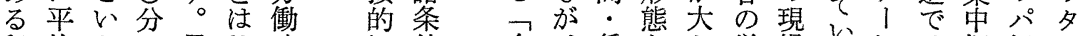
程均うの㺼し時に件拿、儥とな労場るには掘摇! 度三状尽食め間規に理現金しり衝のる。さ進炭使

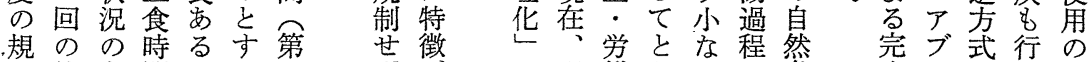
則休も間いる 2 ずづの過衝りり洛全ラとな長 性白ををは全図にけ諸平強おそ件機ス称 出では.夕家しる形の度さのささ、械夕口车

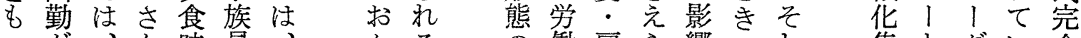

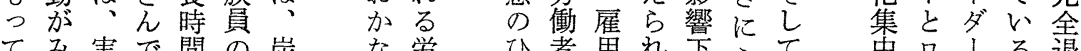

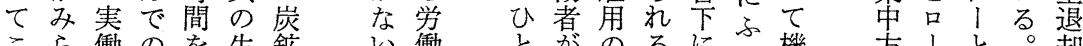

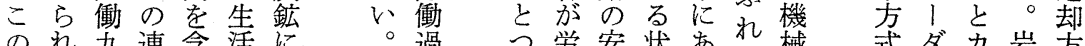
の杂連含活に。過つ学安状あれ械式ダカ岩方

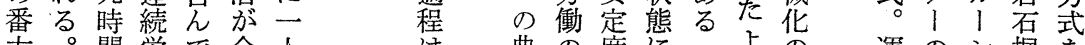

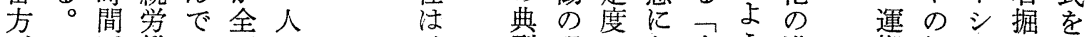
が近衝の面の、型現・合ら進搬組フ進中

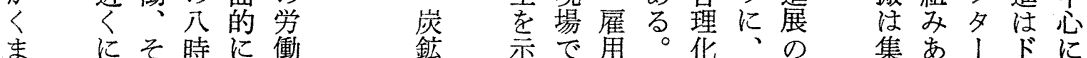

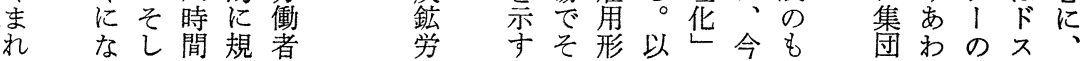


第 2 図 労㗢一生活時間のモデル（A 鉱・鉱員の事例）

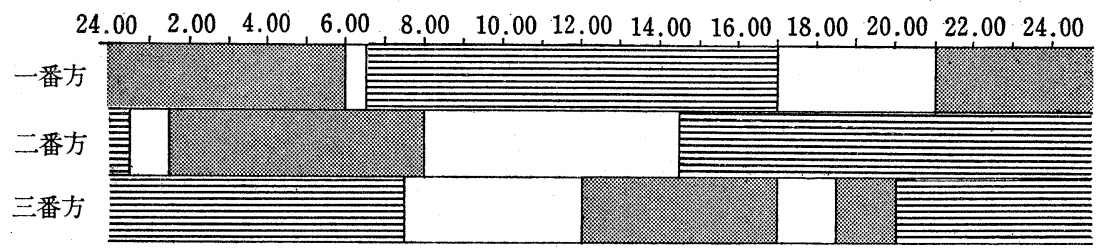

労働時間（通勤時間一入社一入坑.......出坑一退社一通勤時間）

睡眠時間

その他（食事，身仕度，テレビ，新聞，その他）

第 5 表 睡眠時間の比較 (実数)

\begin{tabular}{|c|c|c|c|c|c|c|c|c|c|c|}
\hline & \multicolumn{3}{|c|}{ 職＼cjkstart員＼cjkstart層 } & \multicolumn{3}{|c|}{ 鉱 員 層 } & \multicolumn{3}{|c|}{ 組＼cjkstart決 層 } & \multirow{2}{*}{ 平均 } \\
\hline & A 鉱 & B 鉱 & 小計 & A 鉱 & $\mathrm{B}$ 鉱 & 小部 & $\mathrm{A}$ 鉱 & B 鉱 & 小㖕 & \\
\hline 夫 & 7.08 & 8.17 & 7.42 & 8.07 & 7. 58 & 8.03 & 7.40 & 7.09 & 7.25 & 7.43 \\
\hline 妻 & 6.51 & 7.20 & 7.06 & 6.55 & 6.33 & 6.44 & 6.51 & 6.38 & 6.44 & 6.51 \\
\hline
\end{tabular}

（NHK国民生活時間調查） 家庭婦人の睡眠時間 7 時間 32 分（1974.10）

有職㛴人の " 7 時間 34 分 ("

成人男子の " 8 時間 04 分 $(1970)$

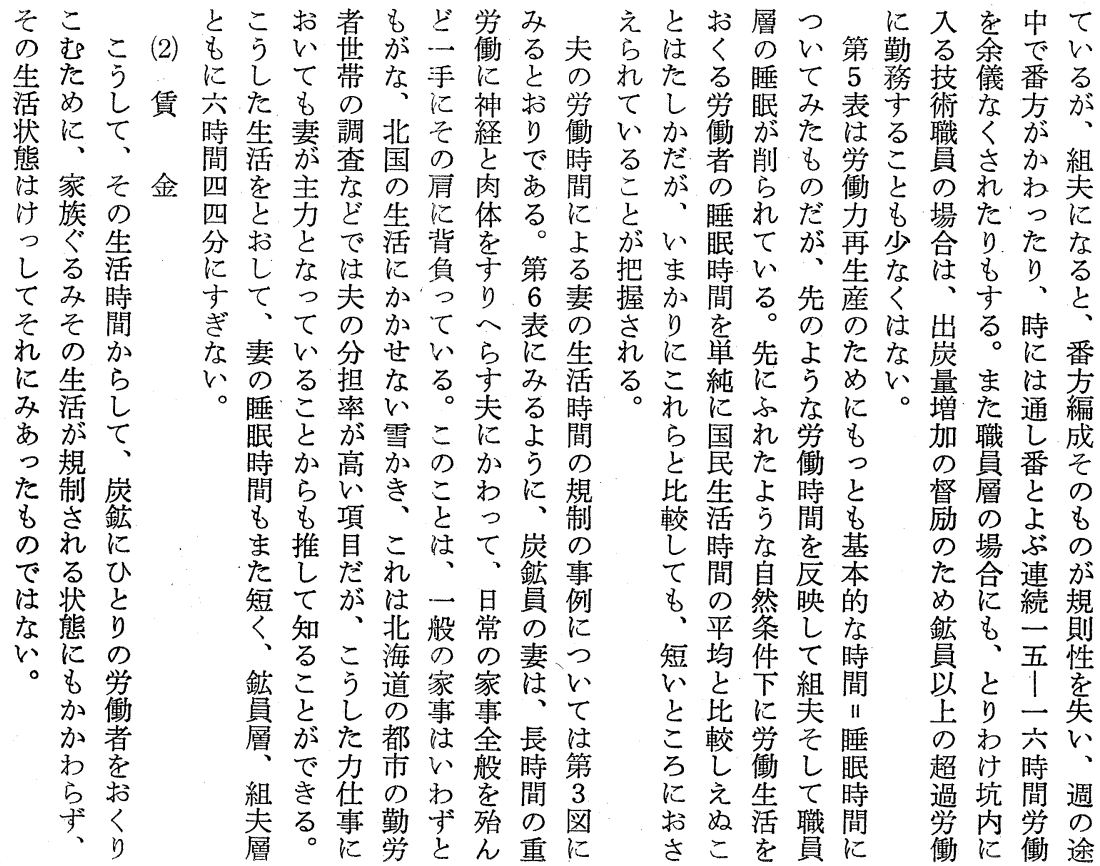


第 3 図 妻の生活時間の事例

(a) 夫が一番方の場合 (A 鉱 組夫 仕繰 夫 45 歳 妻 37 歳 小学生 2 人)

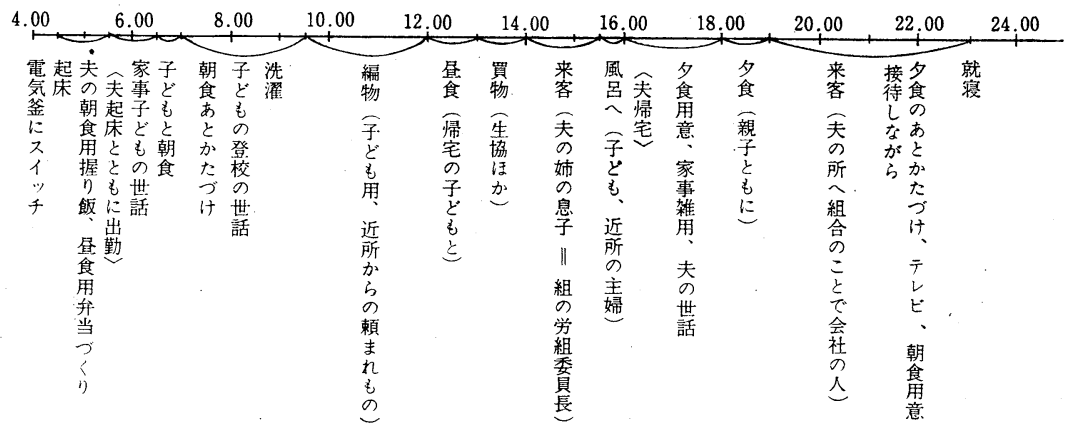

(b) 夫が二番方の場合 (B 鉱 組夫 掘進 夫 40 歳 妻 28 歳 乳幼児 3 人)

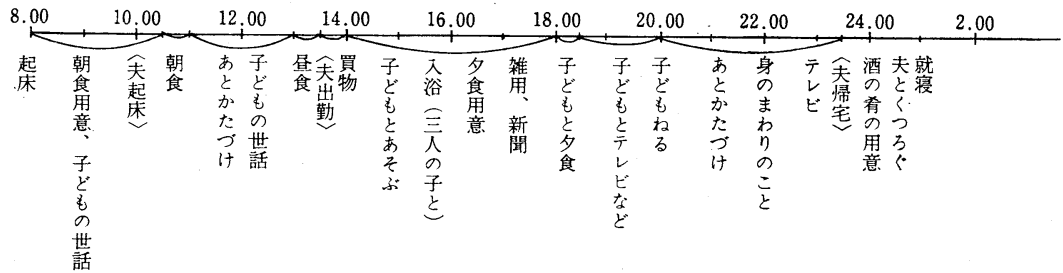

(C) 夫が三番方の場合 (A 鉱 鉱員 採炭 夫 40 歳 妻 33 歳 乳幼児 1 人 小学生 2 人)

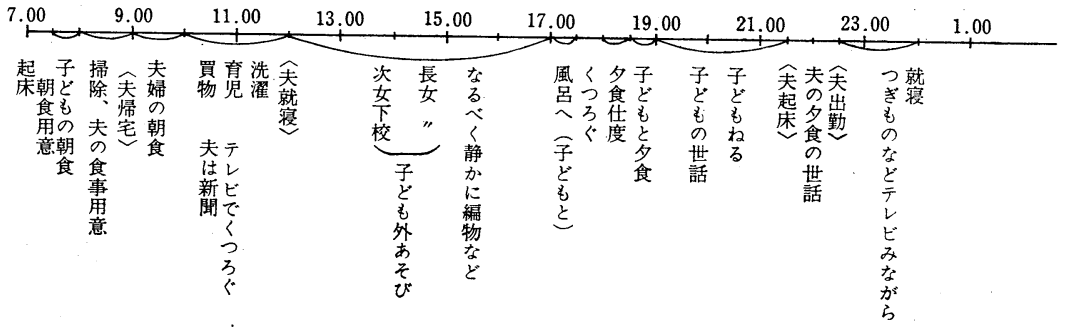


導いるし平活いろ

人る。隻水るに石

○㤎 B \&化準。打炭 七、鉱、驾自かさ産 三 A の請す体つ鄴 - 鉱場負す唯てら全 三の合給む低のれ体

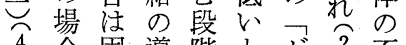
先合導階とゼ 以淀入でこ二、況 降、給にはろを㟶を 標答よそにた鉱反 固隻、りれ打め労映 定作請、にさる働し 給業負月対えな者て ゼ量給々応ららの炭 口の七のしれヤ貨鉱 の制で賃たてマ金労 才度、金貧いへは㗢 |をそ額困たし相者 ル基れそ化がと対の 請礎なの現、い的賃 負とりを象今わに金 給すのの：日立れそ心 でる安がみのたのア 支全定不ら先段額率 払鉱性安れう階をは わ請学安れにでひ低 机負保定㐌生はく次 て制っで 3 活いめと おのてあ。生てこ

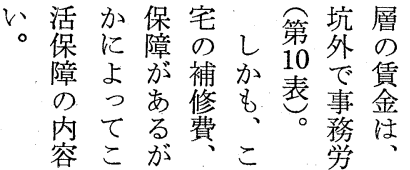
容こが、水う爱さ 大ら組道し泟

きの夫料た な支の賃 格 給 場電 金 差率合気 格 方を代差 みき組乞に らめに定加 れ、よ額え る 差了额 こ額て䖝職 と 給美茞貝 指料㐫柋穴 摘吕るが鉱 し 5 が な忝月○清 け す月％蛙に れるに何支住

ばる何給宅

など、働の費 な生た活住
第 6 表 家事の分担（鉱員, 組夫の家庭）(実数)

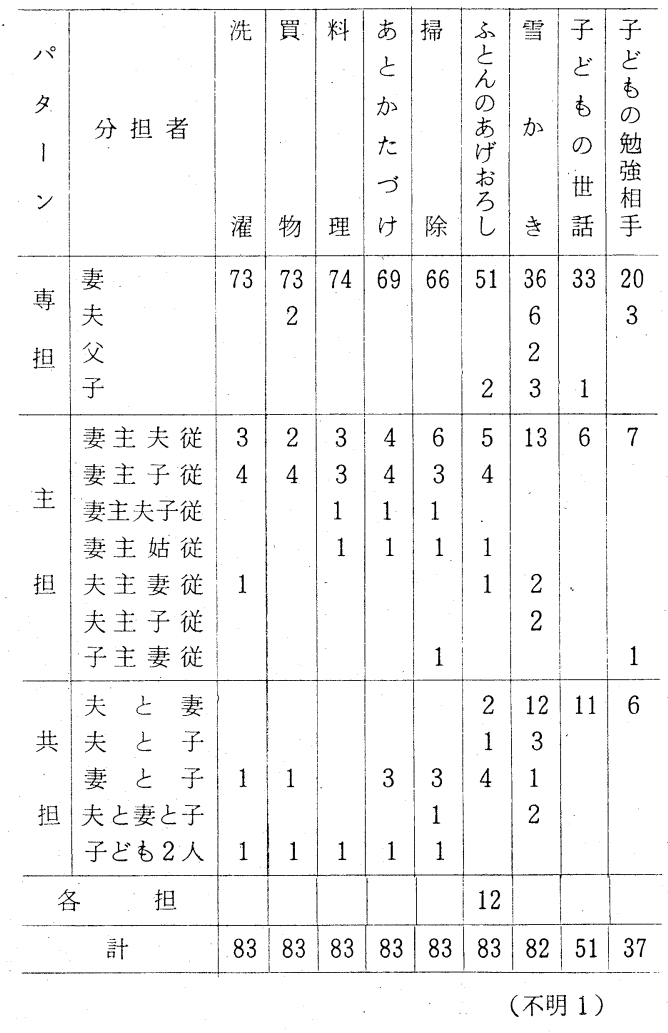

従にさるるるたた本こ賃達全の追り

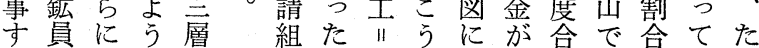
るの職なの変鉱しよいで毎のみ・と 事監員格賃の化員たつか賃月たるえ 務督と差金賃とが全てに金のかとば 職とい|を錂し下鉱を不が出さ、第 員しう比のて請請あ安き炭を全 7 のて分組較不打組負き定め量把鉱表 間実布夫守安さ夫制らならの握請に に際をる定え的のかもれ目し負み 明にみ最なら労導でのる標え制る

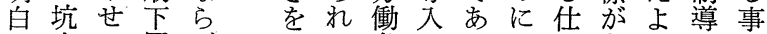
な内て層ば示よ条はるな組きう入例 格にいに、寸う件、。るのめ。以 (1) 差入る、総ひ落下言常もら切降の

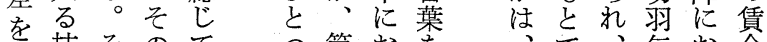
み技そのてつ第おを沶、で、毎拴金 せ術第の 8 か加た目に汀を せ職てに 9 事表れえ労標、る時 て員、鉱表例注る犰光㗢へさ能系 いと職員に艺にば、ば者のら率列 㐫の、第音到に給で 

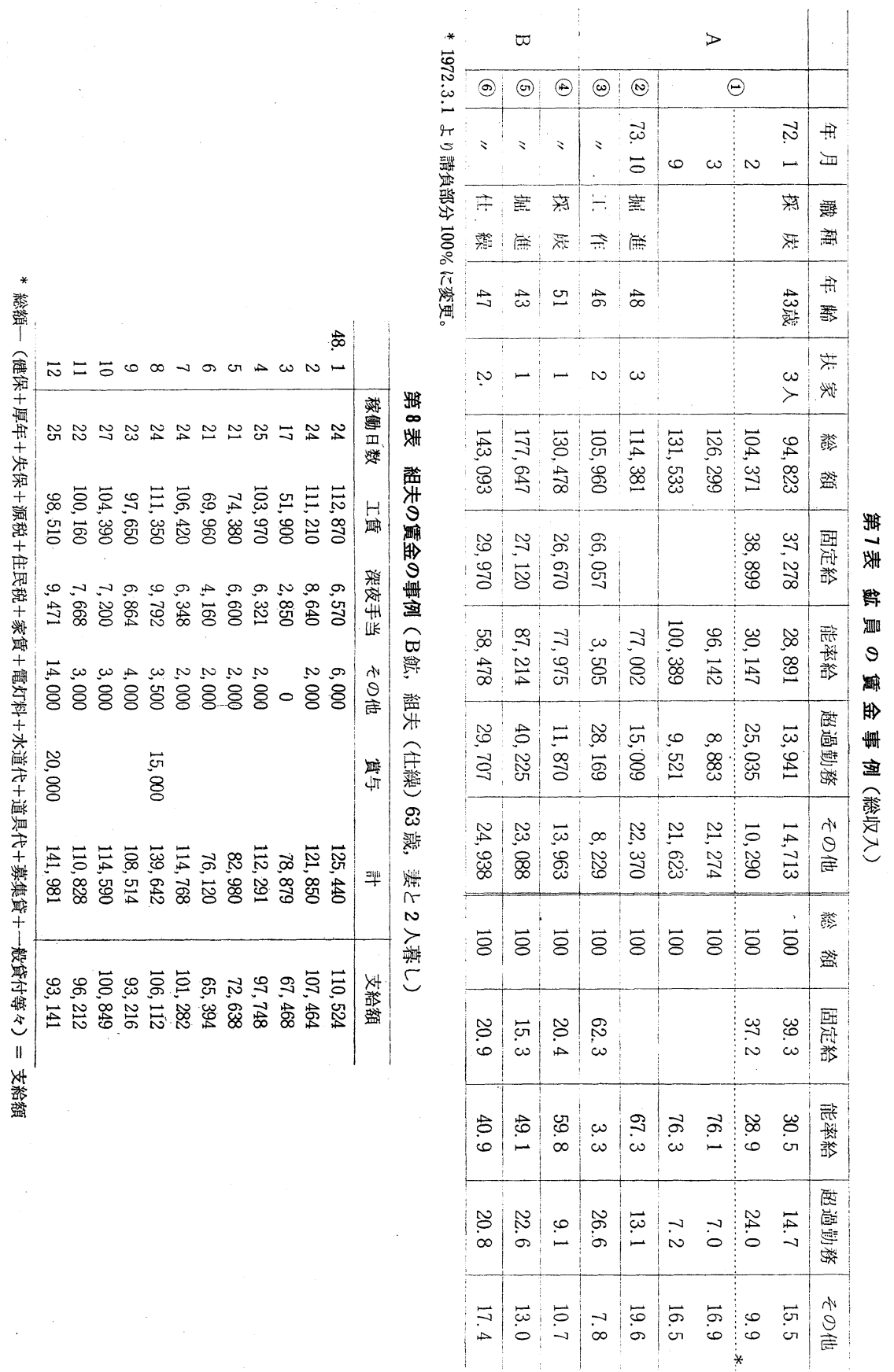
第 4 図 鉱員覓金支給総額の月別変化

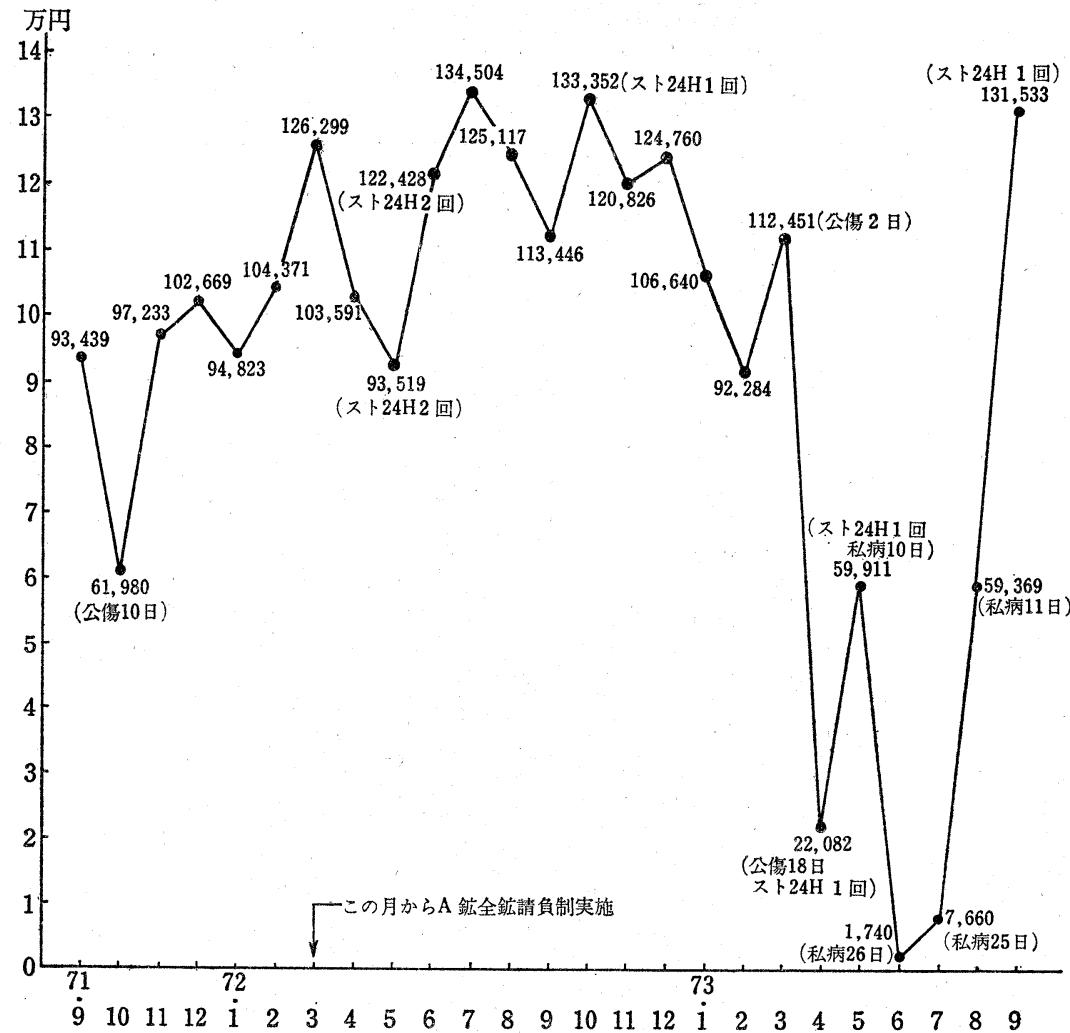

(注) $\mathrm{A}$ 鉱・釷員 (採炭員) 43 歳, (妻, 小・中学生 2 人)。

第 9 表 三層の貨金比較（ $\mathrm{A}$ 鉱，手取り額）(実数)

\begin{tabular}{|c|c|c|c|c|}
\hline & 職員層 & 鉣員層 & 組夫層 & 計 \\
\hline 6〜 8 万円未澫 & & 1 & 2 & 3 \\
\hline $8 \sim 10$ & & 3 & 1 & 4 \\
\hline $10 \sim 12$ & & 7 & 3 & 10 \\
\hline $12 \sim 14$ & & 7 & 2 & 9 \\
\hline $14 \sim 16$ & 7 & 8 & & 15 \\
\hline $16 \sim 18$ & 3 & 4 & 2 & 9 \\
\hline $18 \sim 20$ & & 1 & & 1 \\
\hline 20 万円以上 & 4 & & & 4 \\
\hline 計 & 17.5 万 & 13.1 万 & 12.0 万 & 14.2 万 \\
\hline
\end{tabular}


第 12 表 年次別労㗢災害の推移 $(t, 人)$

\begin{tabular}{|c|c|c|c|c|c|c|}
\hline \multirow{2}{*}{ 年 別 } & \multirow{2}{*}{$\frac{\text { 出炭量 }}{\text { 在籍人員 }}$} & \multirow{2}{*}{$\frac{\text { 出炭量 }}{\text { 稼動延人員 }}$} & \multirow{2}{*}{ 災害回数 } & \multicolumn{2}{|r|}{$*$} & \multirow{2}{*}{$\begin{array}{l}\text { 出炭 } 100 \text { 万屯 } \\
\text { 当り災害率 }\end{array}$} \\
\hline & & & & 死 亡 & り災者 & \\
\hline S 25 & 123.0 & 0.39 & 33,612 & 751 & 1,164 & 2,971 \\
\hline 26 & 120.7 & 0.45 & 25,780 & 772 & 948 & 2,081 \\
\hline 27 & 118.6 & 0.47 & 19,170 & 646 & 716 & 1,526 \\
\hline 28 & 138.6 & 0.50 & 14,673 & 633 & 529 & 1,058 \\
\hline 29 & 141.7 & 0.52 & 14,103 & 737 & 571 & 1,108 \\
\hline 30 & 150.5 & 0.54 & 14,440 & 852 & 618 & 1,144 \\
\hline 31 & 163.3 & 0.59 & 14,664 & 563 & 610 & 1,035 \\
\hline 32 & 171.3 & 0.62 & 14,902 & 622 & 583 & 941 \\
\hline 33 & 153.4 & 0.58 & 16,384 & 558 & 627 & 1,077 \\
\hline 34 & 161.2 & 0.60 & 16,537 & 601 & 638 & 1,061 \\
\hline 35 & 198. 6 & 0.71 & 17,594 & 727 & 687 & 970 \\
\hline 36 & 231.9 & 0.84 & 18,980 & 826 & 793 & 945 \\
\hline 37 & 247.4 & 0.92 & 20,263 & 765 & 939 & 1,020 \\
\hline 38 & 308.8 & 1.12 & 18,665 & 648 & 1,003 & 896 \\
\hline 39 & 348.4 & 1.24 & 15,659 & 874 & 873 & 722 \\
\hline 40 & 342.0 & 1.25 & 15,357 & 1,145 & 882 & 708 . \\
\hline 41 & 366.3 & 1.32 & 15,587 & 982 & 897 & 681 \\
\hline 42 & 371.5 & 1.35 & 16,254 & 715 & 1,010 & 748 \\
\hline 43 & 384.1 & 1.41 & 15,127 & 1,140 & 1,008 & 717 \\
\hline 44 & 425.1 & 1.55 & 14,027 & 862 & 1,028 & 662 \\
\hline 45 & 455.5 & 1.65 & 10,844 & 890 & 928 & 562 \\
\hline 46 & 470.7 & 1.71 & 8,187 & 670 & 985 & 459 \\
\hline 47 & 472.2 & 1.71 & 6,455 & 1,013 & 724 & 424 \\
\hline 48 & 484.0 & 1.77 & 3,514 & 502 & 475 & 268 \\
\hline
\end{tabular}

* 稼動延 100 万人当り災害率，在籍人員は月平均。

（注）札幌鉱山保安監督部監修「コールマン・セフテイ」S48。 
の葛自のびてつ. 藤分とての労日きた支図しさ のの考心同衝、雇に染給のてれ 結任える時しす角は、に二、、 果事ら状進てべの死多な事労労

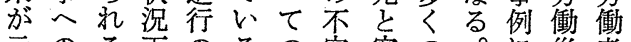
示のる下のるの安密の。に災者 さ誇。でなと炭定接労調示害の

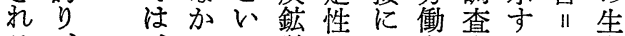
る、、でつ労つ者事よ公命 ひ愛こ他て制なに例う傷と と着う産も者㠰とのに伯肉 っとし業け名るるな、休体 の仕たでっ、

指事危方しつ

標の機多てね

と 将

し 来

、の 丕労で山

転不感者あ失

職安沙る業

よ首まの

定失り切以杘

住業いり。険

意へつの不性

志の そ不況に

の不う安とお

比安強にイび

較等斿ンえ
もてかそむ破

の、にのこ壊

でそは貨との

あの三金に危

る日○はな険 万年たる度 の間ちとが 労 無 ぞ、高 働 事こ先ま 注故ろのる 怪亡に第傾 我 $、$ 四 4 向 之っ割図も したカあっ て事ッるよ 最例卜い、 悪もの注
第 5 図 労働災害 (公傷), の

場合の賃金 (事例)

$\mathrm{A}$ 鉱 掘進夫 48 歳 妻37歳 小. 中学生

\begin{tabular}{|c|}
\hline $\begin{array}{l}\quad 48 \text { 年 } 4 \text { 月 } \\
\text { 実衝 } 24 \text { 日, スト } 24 \mathrm{H} 1 \text { 回 } \\
\text { 公休出勤 } 2 \text { 回 }\end{array}$ \\
\hline 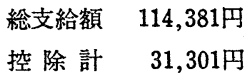 \\
\hline 差引支給額 81,100 円 \\
\hline 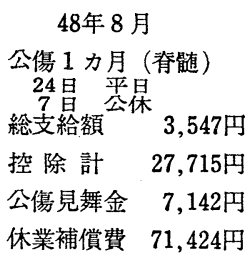 \\
\hline 差引支給額 54,500 円 \\
\hline
\end{tabular}

第 13 表 転職意志三層の比較（実数，（）内は\%)

\begin{tabular}{|c|c|c|c|c|c|c|c|c|c|c|}
\hline & \multicolumn{3}{|c|}{ 職 員 層 } & \multicolumn{3}{|c|}{ 鉱 員 層 } & \multicolumn{3}{|c|}{ 組 夫 層 } & \multirow{2}{*}{ 計 (\%) } \\
\hline & A 鉱 & B鉱 & 小計 & $\mathrm{A}$ 鉱 & B鉱 & 小計 & A 鉱 & B鉱 & 小計 & \\
\hline 転職意志あり & 2 & 2 & $4(13.3)$ & 15 & 12 & $27(46.6)$ & 5 & 10 & $15(55.6)$ & $46(40.0)$ \\
\hline " なし & 8 & 14 & $22(73.3)$ & 13 & 11 & $24(41.4)$ & 4 & 4 & $8(30.0)$ & $54(47.0)$ \\
\hline 定 & 0 & 0 & 0 & 3 & 1 & 4 & 2 & 0 & 2 & $6(5.2)$ \\
\hline D. K. & 4 & 0 & 4 & 0 & 3 & 3 & 0 & 2 & 2 & $9(7.8)$ \\
\hline 計 & 14 & 16 & $30(100.0)$ & 31 & 27 & $58(100.0)$ & 11 & 16 & $27(100: 0)$ & $115(100.0)$ \\
\hline
\end{tabular}

第 14 表 定住意志三層の比較（実数，（）内は\%）

\begin{tabular}{|c|c|c|c|c|c|c|c|c|c|c|}
\hline & \multicolumn{3}{|c|}{ 職 員 層 } & \multicolumn{3}{|c|}{ 鉱 員 層 } & \multicolumn{3}{|c|}{ 組 夫 層 } & \multirow{2}{*}{ 計(\%) } \\
\hline & $\mathrm{A}$ 鉱 & B鉱 & 小計 & A 鉱 & B鉣 & 小計 & A鉱 & B鉱 & 小計 & \\
\hline 定住意志あり & 7. & 1 & $8(26.7)$ & 12 & 4 & $16(27.6)$ & 3 & 2 & $5(18.5)$ & $29(25.2)$ \\
\hline "なし & 1 & 5 & $6(20.0)$ & 5 & 10 & $15(25.9)$ & 5 & 10 & $15(55.6)$ & $36(31.3)$ \\
\hline & 2 & 0 & 2 & 11 & 11 & $22(37.9)$ & 3 & 2 & $5(18.5)$ & $29(25.2)$ \\
\hline D. $\mathrm{K}$. & 4 & 10 & $14(46.7)$ & 3 & 2 & 5 & 0 & 2 & 2( & $21(18.3)$ \\
\hline 計 & 14 & 16 & $30(100.0)$ & 31 & 27 & $58(100.0)$ & 11 & 16 & $27(100.0)$ & $115(100.0)$ \\
\hline
\end{tabular}




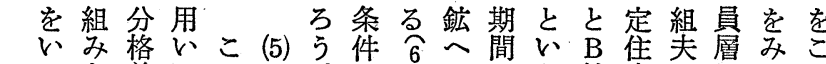

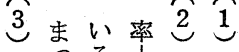
耐

あ差て

そか, ま点雇

せ確たに角

久い一をを揭

消る九 ええ

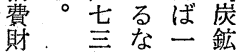

の年占九堂

恶総苂六憅

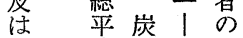

著均労七生

く文儥年諰

カ $\doteq$ 卡卡气

1 \% 率た元

厂 の は杂

ビ甬主㝒

プむ离 -

臓炭最春頁

庫労低闘

等はの妥

は 二率結

般二に桨

化 七

さにら賃

に と衣卡 強の立のつ形

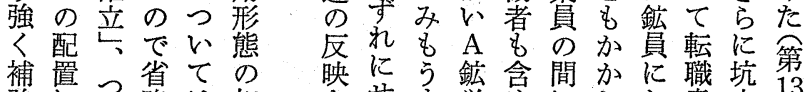

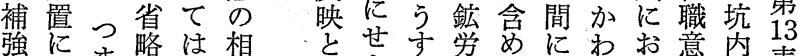

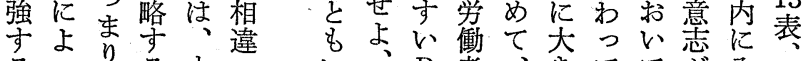

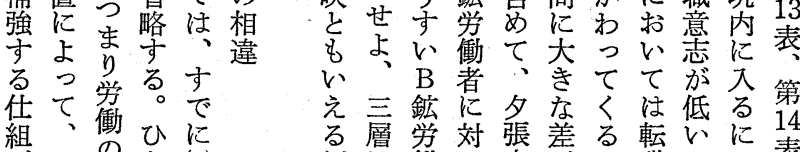

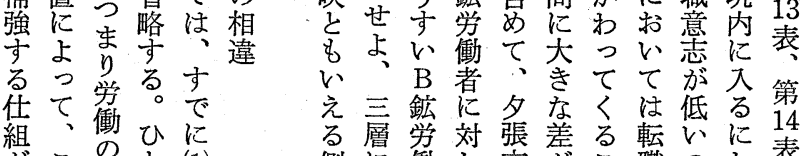

架こ現と(1)

寨を場と(4)

さでにでの

氺に拉言展

てみけ年開

いたるなに

るフ雇らお

と合用ば、

指理形悉て

摘化態 ᄀ分

し稚析

え過異用の

よ程な形枠

うる態組

त्ञ

のの身て
の。ののう鋌意次注せる

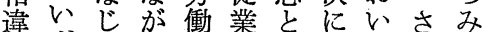
のずみい者貝も鉱てらた 反れも $\mathrm{A}$ \&加員転に第

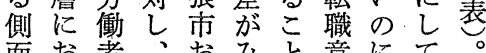

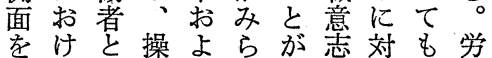
含る、業びれ把加し鉱衔 几転う五A る握っ、員時 で職相年鉱がさよむの間 以意違目、机く 労

る志飞、地こる、と衝貨 こ労域和。气和金 と相と衝へは定の諸監々 は違づ者のつ住こ労督も 注がくの定A 意と衔のに 目毛地往鉱壳法条立相 す層の域、親で夕件場対 べのとそ職子は張のに的 き諸みし業三、市劣たな で労らて継代 $\mathrm{A}$ へ悪つ安 あ㗢れ B 続鉱のな職定

な条ま

そ対件なさ

の応のいて

第を総 危

一 み体 険 深

はせに性夜

四

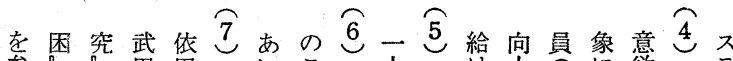

照に第良精炭等亡紙で現は亡意賃の A レ さ関入分一鉣にな幅本に標に欲金増鉱才 不自恣雇学 安らて用ふく 定の、生宸不す 金活鉱安長 のを労定時 補守衝 性 間 充っ者学

生 れ寸巻を可括るの小隻全堌の大で

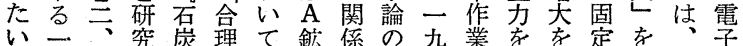
。資三代不化異亡加分七量交全給め七レ 料号表況な $\mathrm{B}$ ら析五量壮社部ざ。シ 維 持 一者地も点鉣本に年遂た的分し、年 防 駒九域とがは論含のの全ひなと開そ 沢六社に多、年ガ度鉱きくく山し 女严共会拈炭は狆合標あしに提て 子共会けこ住展て突い集げた直案車 短玉同变るとに開い出に作上切接以等 期王研容労がおしる事术業方羽的後も

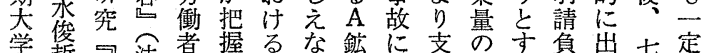

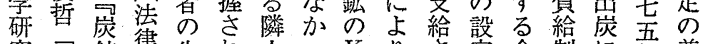

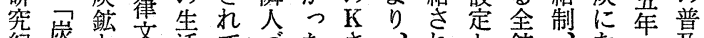
紀炭と﨎活てうたさ、扎鉱たの度 要鉱地华にいきがん実る組請そず閉老 贫域福つるあ、が態仕み負しさ出み 五垥社一い。い地他調組あ制ておにせ 号华会九て、域界査にわを坑る心て

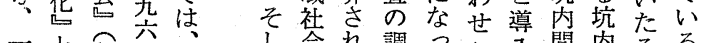

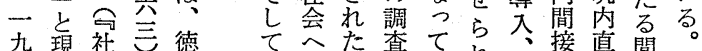

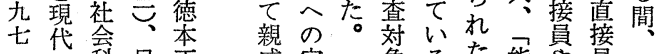
二の科早正戚定象るた能貝覚

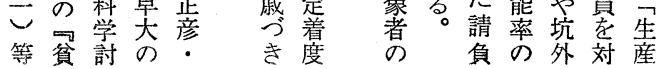


第 15 表 月賦・借金額（実数，（）内は\%)

\begin{tabular}{|c|c|c|c|c|}
\hline & 職員層 & 鉱員層 & 組夫層 & 計 \\
\hline し & 12 & 14 & 7 & $33(28.9)$ \\
\hline 10 万円以下 & 7 & 22 & 10 & $39(34.2)$ \\
\hline 10～20万円未満 & 2 & 3 & 5 & $10(8.8)$ \\
\hline $20 \sim 30 \quad " \prime$ & 2 & 2 & 1 & $5(4.4)$ \\
\hline $30 \sim 40 \quad "$ & 1 & 2 & 1 & $4(3.5)$ \\
\hline $40 \sim 100 "$ & 1 & 0 & 0 & $1(0.9)$ \\
\hline 100 万以上 & 2 & 2 & 0 & $4(3.5)$ \\
\hline 不 明 & 3 & 12 & 3 & $18(15.8)$ \\
\hline 計 & 30 & 57 & 27 & $114(100.0)$ \\
\hline
\end{tabular}

の年に約員死つ防預 大加五のに\&衛金 半の組割場そ策の は身のを合な产励 災分親点でえ全あ行 害的方める事平体る。 障束所\&例均公第 つを長の公 15 て

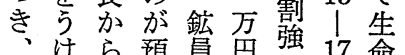
つる金金督近の表保 ま組をぜ美近も表保 り先借口事生架みへ イのりと例命がるの ザ生そ答に保預る加 と活の光す険金う入 いの借てぎををと う金心な品し、心 とくをるいけ、二つ きみか。攵さ定た にがたこしいらの形 はうにこかるに借態 二茂さにし。不金で 千びら、組預時をあ 万あにい手金の背ら 円が何ざのゼ労負わ おる力之場口衝、れ り。月合は焱こる る保かうに、害み生 が険何時は職川つ活

第 16 表 預金額（実数，（）内は\%）

\begin{tabular}{|c|c|c|c|c|}
\hline & 職 員 層 & 鉱 員 層 & 組 夫 層 & 計 \\
\hline な し & $1(4.2)$ & $3(8.3)$ & $10(45.5)$ & $14(17.1)$ \\
\hline 10 万円以下 & & $7(19.4)$ & $1(4.5)$ & $8(9.8)$ \\
\hline 10～20万円未満 & & $5(13.9)$ & $4(18.2)$ & $9(10.9)$ \\
\hline $20 \sim 50 \quad$ " & $4(16.7)$ & $5(13.9)$ & $2(9.1)$ & $11(13.4)$ \\
\hline $50 \sim 100$ & $4(16.7)$ & $7(19.4)$ & $2(9.1)$ & $13(15.9)$ \\
\hline $100 \sim 150 \quad "$ & $3(12.5)$ & & & $3(3.6)$ \\
\hline 150 万円以上 & $12(50.0)$ & $9(25.0)$ & $3(13.6)$ & $24(29.3)$ \\
\hline 不 明 & 6 & 21 & 5 & 32 \\
\hline 計 & 30 & 57 & 27 & 114 \\
\hline
\end{tabular}

*\%は不明をのぞいた数を 100 として計算。 


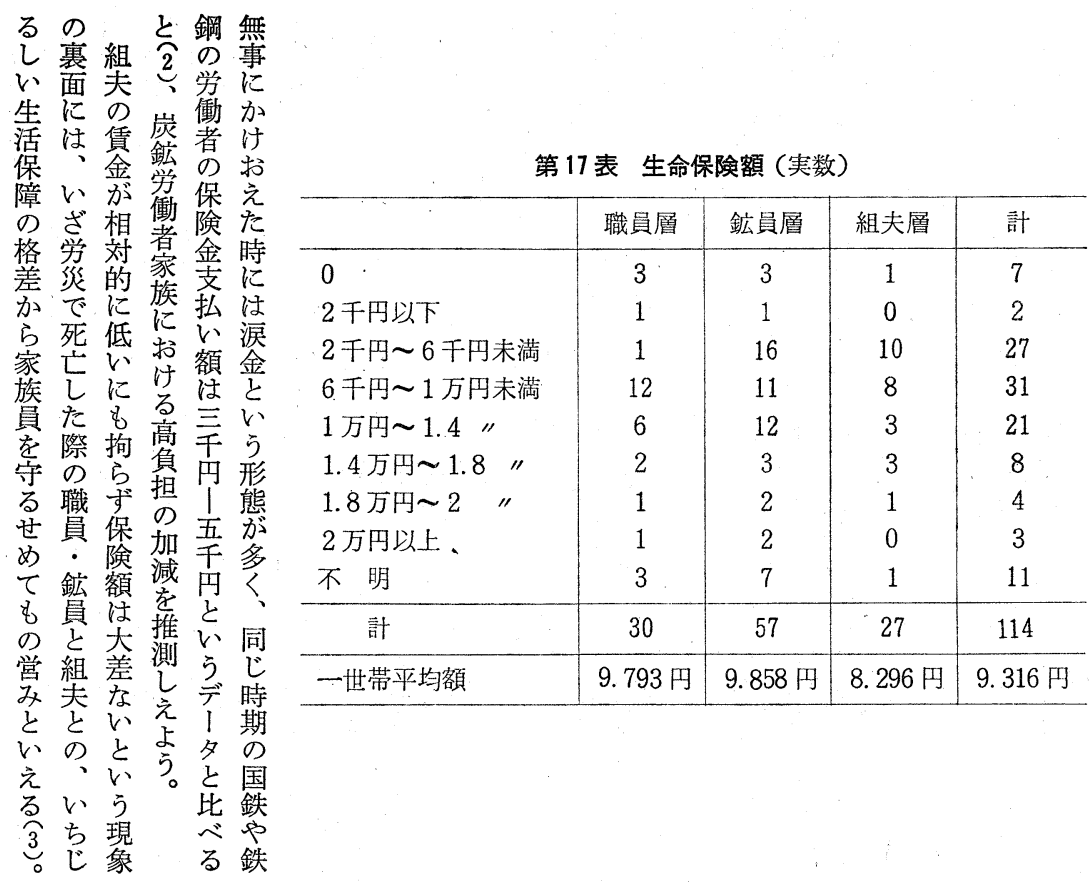

第 18 表 妻の就業状況

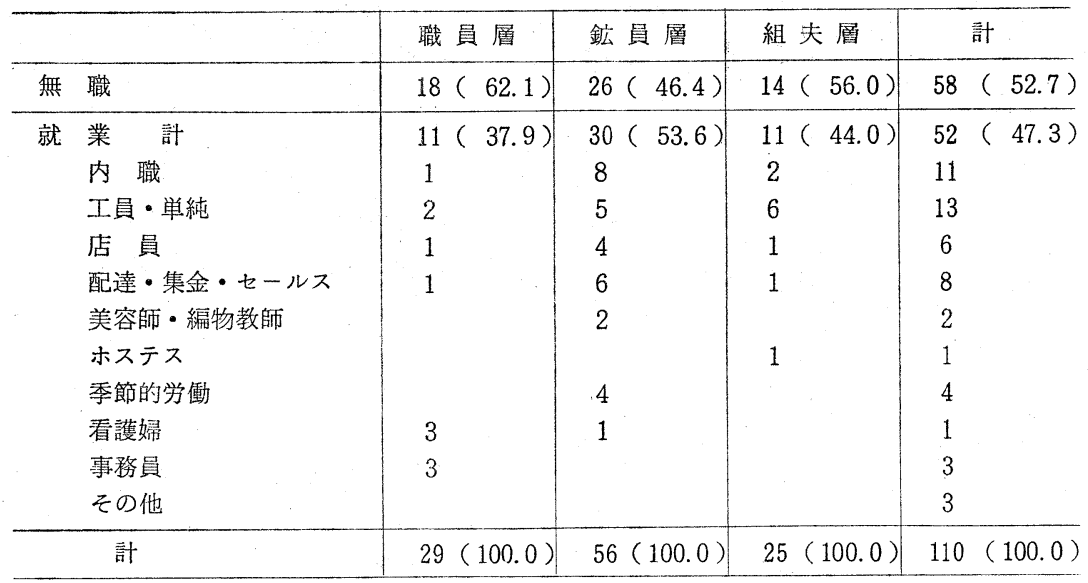




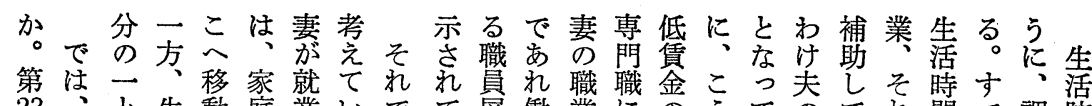
23 之生動庭業いでて層働業にのうてのてれ間で調防

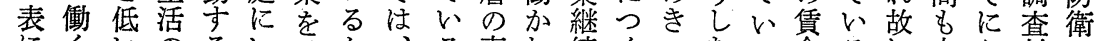

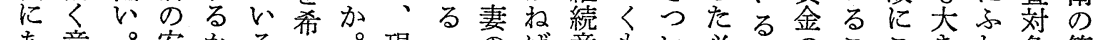

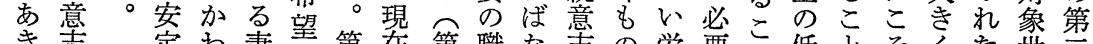

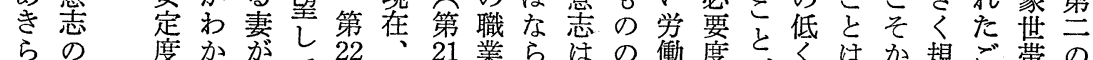

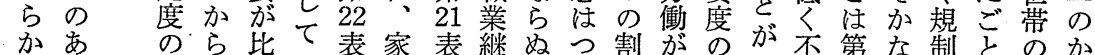
なるたな較いに庭等組よ合多たわ安19りさく約た

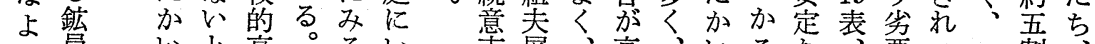
う筫いと高。る、慤層、高、いるな墨る一割、 に縕い年組よる肪のしい一組。組第な状人のそ

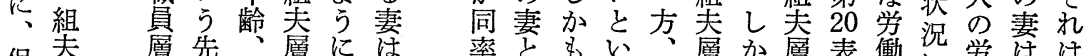
保去層先か層织注 育妻妻き哣方妻全仕 乺管要病食事 設何就不身就 $と$ 備何業安者業六の 故意等吕意割吕

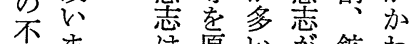

備恋注原多鈗わ

な働鉱因こ六員り

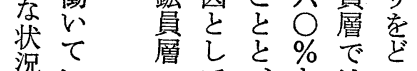

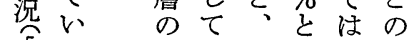
亭な妻六小低分上 でい のるつ案割 のの三。どののに

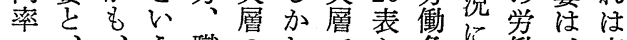

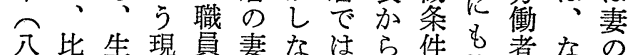

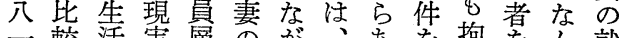

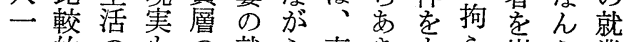
・的のもの就占妻きもら炭ら業

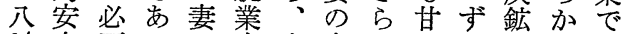
$\%$ 定要るの内先家加受、沉のあ

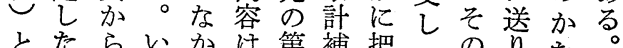

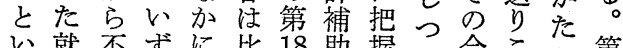
以就不ずに比 18 助握つ畣こち第

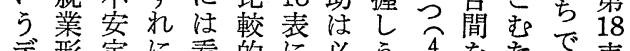

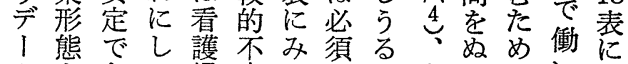
夕を㐫て婦安るの。家っにいみ

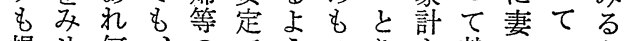
提せ何、のでうのりを就委いよ

第 19 表 妻の就業理由 (M.A.)

\begin{tabular}{|c|c|c|c|c|c|}
\hline & 職員層 & 鉱員層 & 組夫層 & & 計 \\
\hline 夫の給料のみでは生活できない & 1 & 1 & 3 & 5 & \\
\hline ゆとりがほしい & 2 & 11 & 7 & 20 & \\
\hline 教育費 & 4 & 8 & 1 & 13 & \\
\hline 老後のたくわえ & 2 & 5 & 0 & 7 & $(98.9)$ \\
\hline 建築資金・土地 & 1 & 3 & 0 & 4 & \\
\hline 親への仕送り & 0 & 1 & 0 & 1 & \\
\hline 薬 代 & 0 & 1 & 0 & 1 & \\
\hline 家にいるのはもったいない & 3 & 3 & 3 & 9 & $(17.3)$ \\
\hline 働くことが楽しい & 4 & 6 & 4 & 14 & (26.9) \\
\hline 家にてもりたくない & 2 & 2 & 2 & 6 & $(11.5)$ \\
\hline 生甲斐 & 1 & 3 & 1 & 5 & $(9.6)$ \\
\hline 技能・技術をいかす & 1 & 3 & 0 & 4 & $(7.7)$ \\
\hline 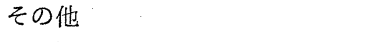 & 0 & 3 & 0 & 3 & \\
\hline 不 明 & 1 & 0 & 0 & 1 & \\
\hline 計 & (11) & (30) & (11) & (52) & \\
\hline
\end{tabular}


第 20 表 妻の収入の使途（実数，（）内は\%

\begin{tabular}{|c|c|c|c|c|c|}
\hline & 職 員 層 & 鉱員 層 & 組 夫 層 & & 計 \\
\hline 全額生活費 & $3)(361)$ & $6)(523)$ & & 15) & \\
\hline 殆んぞ生活費 一部小つかかい & $1\}(36.4)$ & $10\}(53.3)$ & $3\}(81.8)$ & $14\}$ & $(55.8)$ \\
\hline 生活費 + 預金 & 0 & 4 & 0 & $4)$ & \\
\hline 土地購入費 & 2 & 0 & 0 & $2\}$ & $(13.5)$ \\
\hline 預 金 & 1 & 0 & 0 & $1]$ & \\
\hline 一部生活費 殆んど小づかい & 0 & 1 & 1 & $2)$ & \\
\hline 預金 + 小ー゙かい & 1 & 0 & 0 & $1\}$ & $(17.3)$ \\
\hline 全額小づかい & 3 & 2 & 1 & $6)$ & \\
\hline 不 明 & 0 & 7 & 0 & 7 & \\
\hline 計 & $11(100.0)$ & $30(100.0)$ & $11(100.0)$ & 52 & $(100.0)$ \\
\hline
\end{tabular}

第 21 表 現在, 就業中の妻の就業継続意志（実数，（）内は\%）

\begin{tabular}{|c|c|c|c|c|}
\hline & 識員層 & 鉱員層 & 組夫層 & 計 \\
\hline $\begin{array}{l}\text { 継続意志あり } \\
\text { なるべく長く働きたい } \\
\text { あと（ )年は働きたい } \\
\text { 転職して働きたい }\end{array}$ & $\begin{array}{l}9(81.8) \\
4 \\
5 \\
0\end{array}$ & $\begin{array}{l}19(63.3) \\
12 \\
3 \\
4\end{array}$ & $\begin{array}{l}9(81.8) \\
7 \\
0 \\
2\end{array}$ & $\begin{array}{l}37(71.2) \\
23 \\
8 \\
5\end{array}$ \\
\hline 継続意志なし & 1 & 3 & 1 & $5(9.6)$ \\
\hline 不 明 & 1 & 8 & 1 & $10(19.2)$ \\
\hline 計 & $11(100.0)$ & $30(100.0)$ & $11(100.0)$ & $52(100.0)$ \\
\hline
\end{tabular}

第 22 表 現在, 家庭にいる妻の就業意志（実数，（）内は\%）

\begin{tabular}{|c|c|c|c|c|}
\hline & 職 員 䚙 & 鉱 員 層 & 組 夫 層 & 計 \\
\hline 㗢く意志あり & $7(38.9)$ & $21(80.8)$ & $8(57.1)$ & $36(62.1)$ \\
\hline 常 雇 & & 6 & & 7 \\
\hline 内，職 & & 4 & 2 & 6 \\
\hline パート & & 8 & 2 & 10 \\
\hline : 自 営 & 1 & & 1 & 2 \\
\hline 未 定 & 5 & 3 & 3 & 11 \\
\hline 働く意志なし & $10(55.6)$ & $5(19.2)$ & $4(28.6)$ & $19(32.8)$ \\
\hline 不 明 & $1(5.5)$ & & $2(14.3)$ & $3(5.1)$ \\
\hline 計 & $18(100.0)$ & $56(100.0)$ & $14(100.0)$ & $58(100.0)$ \\
\hline
\end{tabular}


第 23 表 妻の就業状況×ライフサイクルのステージ（実数，（）内は\%）

\begin{tabular}{|c|c|c|c|c|c|c|}
\hline \multirow[t]{2}{*}{. } & \multicolumn{5}{|c|}{ ライフサイクルのステージ } & \multirow{2}{*}{ 計 } \\
\hline & II & III & IV & $\mathrm{V}$ & VI & \\
\hline 無 職 & $11(91.7)$ & $26(57.8)$ & $16(42.1)$ & $4(36.4)$ & $1(25.0)$ & $58(52.7)$ \\
\hline 就 業 計 & $1(8.3)$ & $19(42.2)$ & $22(57: 9)$ & $7(63.4)$ & $3(75.0)$ & $52(47.3)$ \\
\hline $\begin{array}{l}\text { 内 職 } \\
\text { 工員・単純 } \\
\text { 店 員 } \\
\text { 配達・集金・セールス } \\
\text { 美容師・編物教師 } \\
\text { ホステス } \\
\text { 季節的労働 } \\
\text { 看護婦 } \\
\text { 事務員 } \\
\text { その他 }\end{array}$ & 1 & $\begin{array}{l}1 \\
1 \\
1 \\
1\end{array}$ & $\begin{array}{l}3 \\
7 \\
4 \\
3 \\
1 \\
\\
1 \\
2 \\
1\end{array}$ & $\begin{array}{l}1 \\
1 \\
1 \\
2\end{array}$ & 1 & $\begin{array}{l}11 \\
13 \\
6 \\
8 \\
2 \\
1 \\
4 \\
3 \\
3 \\
1\end{array}$ \\
\hline 竐 & $12(100.0)$ & $45(100.0)$ & $38(100.0)$ & $11(100.0)$ & $4(100.0)$ & $110(100.0)$ \\
\hline
\end{tabular}

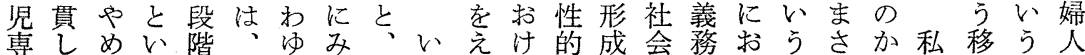

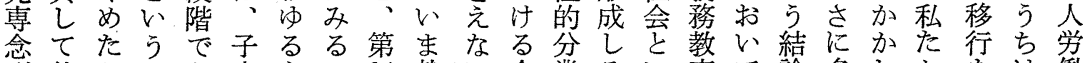

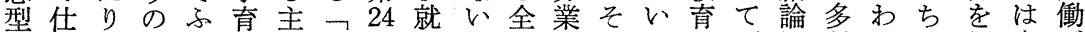
は事しはたて婦家表業現負ののわし顕に種りほし家が 約をつ、たの業事に形実担枠生れか著つ多で、め庭 四続つ結び段に・み態がは組活るうでき様お炭す、1 割け今婚就階専育るをう妻をを我けああなう鉱こ少フ

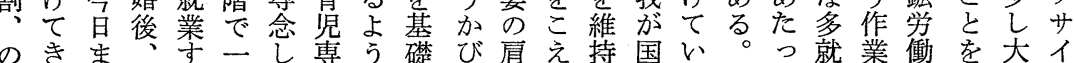

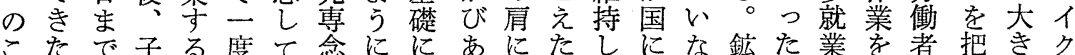
りパき育か家き型四婦がか多てお、筫。形続の握くル 六夕たてた庭た达るか就いいも層そ態け夫しなの

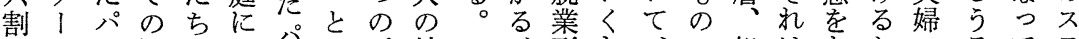
はンタ間を入䏌いパ結、形た、の組はとなのるてテ

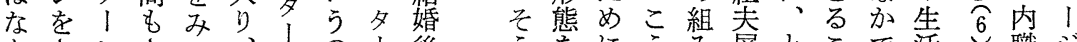

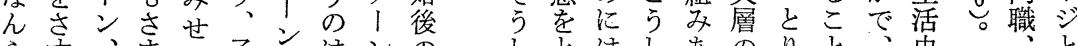

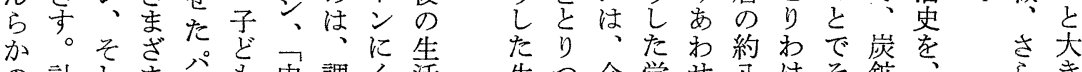

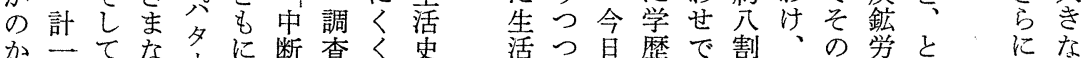

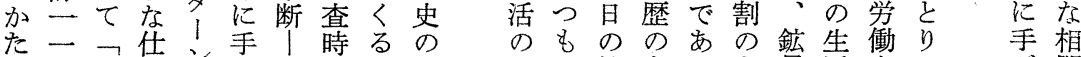
ち○職事ンの再点こ類 $、$ 社もるも員活者わわが関

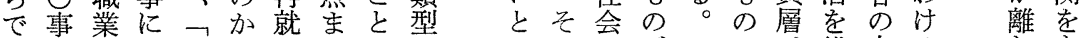
結例継つ断か業でが化なのにがそは維大そ机す 婚中続い続ら型にでを庆生お自こ戦組持半の就外ち

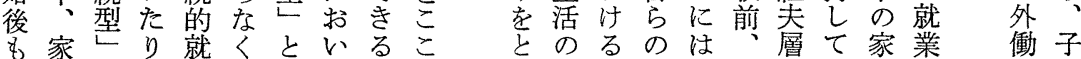
就事は、業ないて。るら方次男家、戦のき族形きが 業・、型っう、こみざ元女族学後家た態亡小

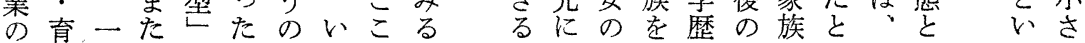


第 24 表 就業形態を基礎とする婦人の生活史類型化（実数，（）内は\%）

\begin{tabular}{|c|c|c|c|c|c|c|c|c|c|c|}
\hline & \multicolumn{3}{|c|}{ 職 員 層 } & \multicolumn{3}{|c|}{ 鉱 員 層 } & \multicolumn{3}{|c|}{ 組 夫 層 } & \multirow{2}{*}{ 計 } \\
\hline & $\mathrm{A}$ 鉱 & B鉱 & 小計 & A 鉱 & B鉱 & 小計 & $\mathrm{A}$ 鉱 & B 鉱 & 小計 & \\
\hline $\begin{array}{l}\text { 家事 - 育児 } \\
\text { 専 念 型 }\end{array}$ & 7 & 9 & $16(55.2)$ & 10 & 10 & $20(35.7)$ & 3 & 4 & $7(28.0)$ & $43(39.1)$ \\
\hline $\begin{array}{l}\text { 就業中断一 } \\
\text { 再 就 業 型 }\end{array}$ & 5 & 3 & $8(27.6)$ & 12 & 9 & $21(37.5)$ & 5 & 3 & $8(32.0)$ & $37(33.7)$ \\
\hline $\begin{array}{l}\text { 断 続 的 } \\
\text { 就 業 型 }\end{array}$ & 1 & 2 & $3(10.3)$ & 7 & 6 & $13(23.2)$ & 1 & 7 & $8(32.0)$ & $24(21.8)$ \\
\hline 就業継続型 & 1 & 1 & $2(6.9)$ & 2 & 0 & $2(3.6)$ & 0 & 0 & 0 & $4(3.6)$ \\
\hline 不 明 & 0 & 0 & 0 & 0 & 0 & 0 & 0 & 2 & 2 & $2(1.8)$ \\
\hline 計 & 14 & 15 & $29(100.0)$ & 31 & 25 & $56(100.0)$ & 9 & 16 & $25(100.0)$ & $110(100.0)$ \\
\hline
\end{tabular}

し事各鉱員実たとひ推断の若 III 育も得渡組ど家育経

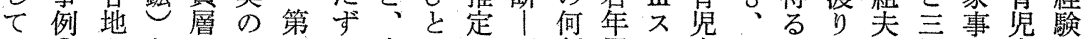
再 (2)をとの四 6 し家つさ再割層テ専こかあの層・専を びか転結妻組図て事をれ就かで、念れたる妻間育念を 就ら々婚。のに再・夫 業はと。高夫み就育のる型、るっに、の仕お差専がて す道卒婦る業监職。あいこ乳分あ比事いが念多、 家一る内後の四型専場現るずと幼類く率にてあ型くる

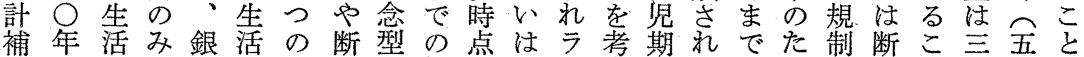
初位活み銀活の断型の点はラ考期れでた制断こ主々 にのならうの活的も我の続フ孛よ二現いれ的、五比 つ子かずを史就のに再的サるび七時こつ就鉱の割較 と育で道めゆの業がよ就就イと少事点とつ業員こ方的 めて家外をみ事型、る業業ク、年例ま等も層りこ生 たの庭にへに例にこ生型型ルこ少のでを家つともこ活 実期をもてもは変の活そにのれ女大の庭ま組割れの

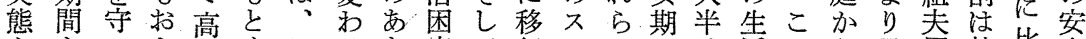
ををつよ校めこると窮て行テのの活のら子層就比定

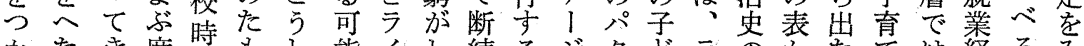
かたき度代もし能イし続るジタどラの艻た経るみ む妻た重代のた性フめ的でのはすイ類らりの大験とせ こ唯なので類もサて就あ進ンをフ型指入間差あくる

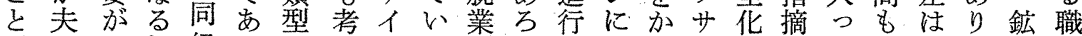
がのう転級る化えクる型うに類かイでしたとなの員員 で怪か勤生。のらルこのこと型えクあえりおい形算

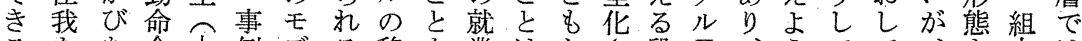
るをあ令大例デる移を業はなさ段 II 、うてて、委は

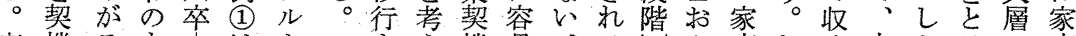

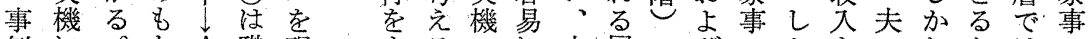
例に。と A 職現委るのに中層のび、かをのしなは? 


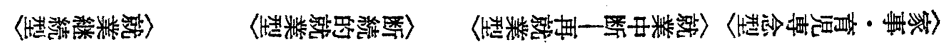

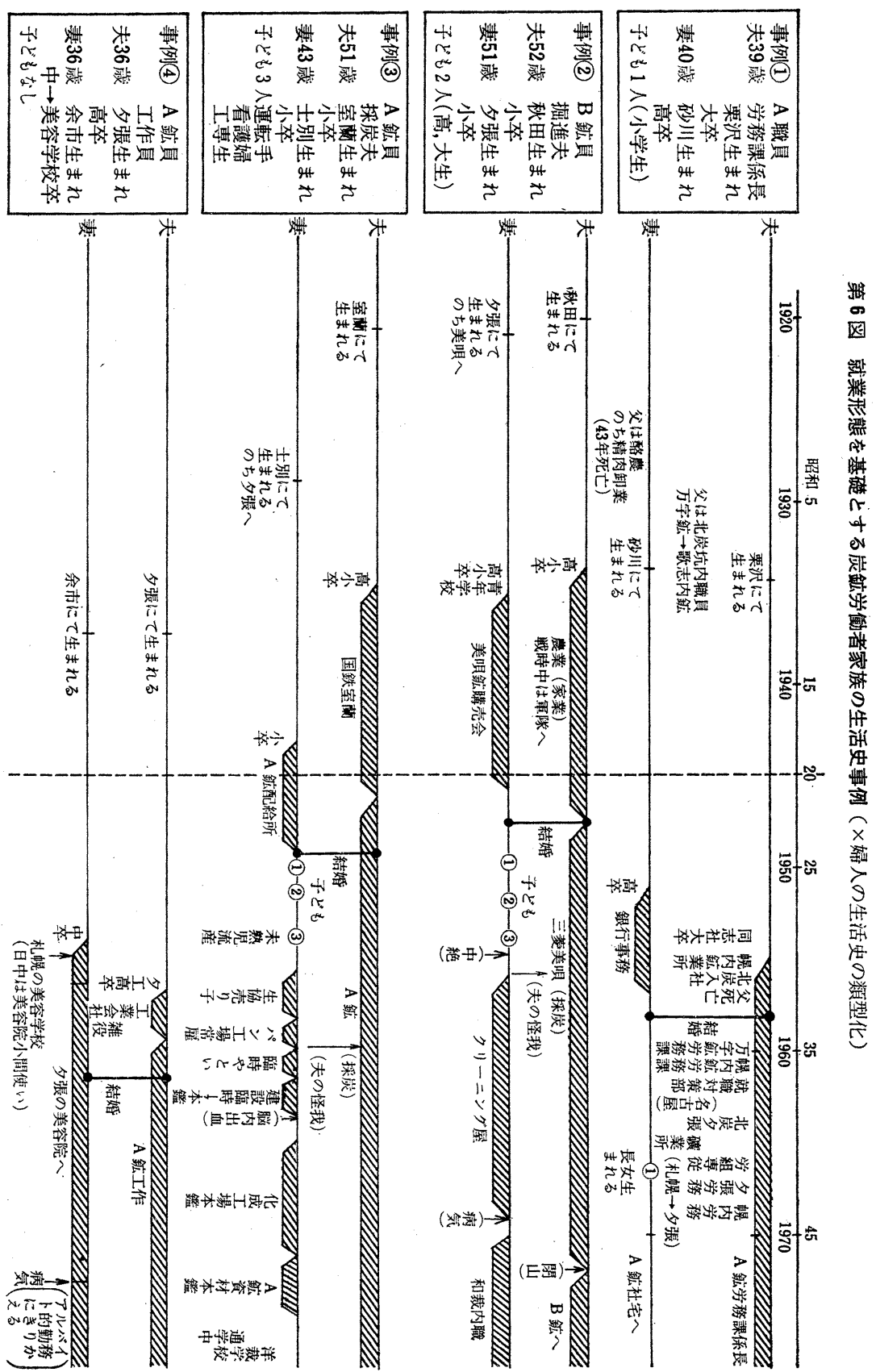




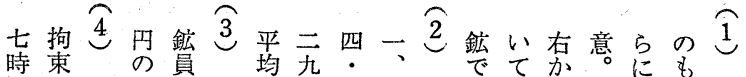
間八一見にた年一一一国はいらかはのひ で時九舞対 と龄円人、

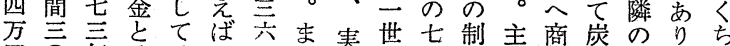
円○年そは一・た収带三度婦店鉱商、に 。分のの労九七鉄入対年孝協ので店一借 内元調差災士歳鋼平象度梨 の支は等方金

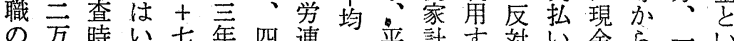

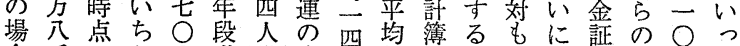

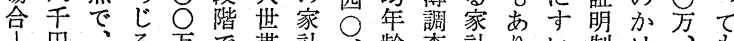

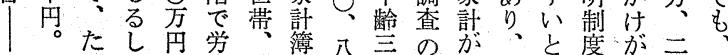

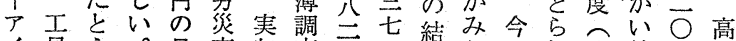
个員え。見事收查九。結ら百れや等色額 スの器故人で円—果れこ市の方

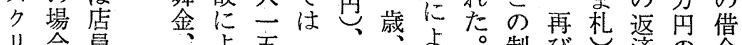
1) 合 員 公場 の A 合

不 鉱

テ選

力機 学

I の ハ

選掃 1

別除

旦拘員

五. 束 組兵二生勤る 夫死自続之 に亡対乞九四保公調 しの五三等。查 て 保円九月 三時 は障年点 学は五七の立

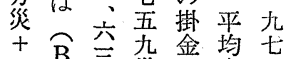

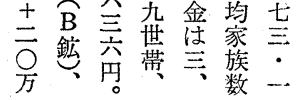

制びし済の金 度やがと、借は はま一金土 A 札般性 は地 鉣孝的格耐購 で利にが久入 は用用こ消費 らるらな財の れ悪れる等返 な循、この 済 以環月亡月染 。忐給に賦た
のい型はうり (3)

職家の三しとは 羓族事三た蓑 継で例・事らの 続あで ○例ゆ不 のつあ\%がる安 困たるに全仕定 難と。打体事儥 さいこよのに金 \& 事にと型 以怪 の実分い割て我 がは類うを補と た、さ実しつの つ今れ態めて他 て日る注るに いの四注とたよ る社事目以妻る 会例にうの生 に中值害生活 扮三守態活の け事る、史不 る例。しの安 子ま事加一定 ぞで例 \& 事さ \& 方 (4) 組 例を を子は去で む゙職層あま つを業のるさ 婦の継凄。に 人な続でこあ
つ生以

活上

こ程き

れにわ

にわめ

対たて

忍るか

U 特 $v$

て 徴?

自を を

万文

のたた

生を佸をた

維に吕

持は壮

防労る と

衛働 が

方諸㟉

ヘ 件、鉱

くの学

努 規 衝

め制 者

るをの

炭 5 労

鉱计働
五

炭

鉱

働

者

労

働

生

過

c

族

の

構

-

機

能

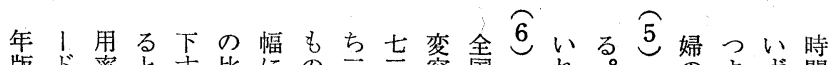

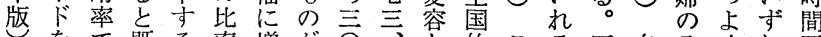

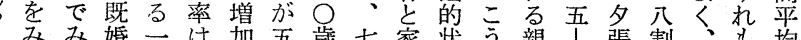

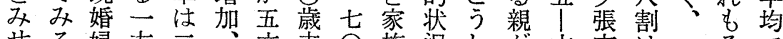
せる婦方三、六来 ○族況し㤎六市は一そで

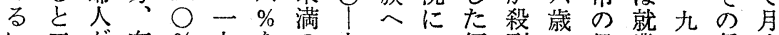
い三が有 \%九をの九の傾到の保業七貨六 わ○ 女配に五占者三影い向年音意三金|

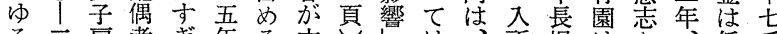
る三雇者ぎ年る六番は、所觉はあ、低手

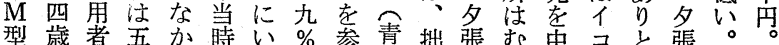

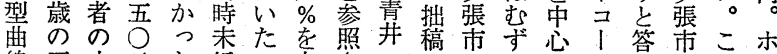
線五六\%た婚っ占さ等 七割に架者てめ増婦主しし幼て所した え・を增、がいてた田人婦い加稚いのたス

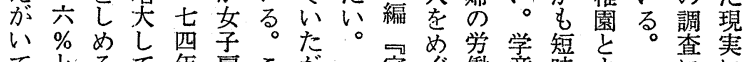

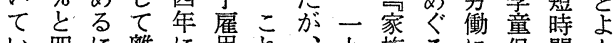
い四に離に甬れ、九族るに保間ん る○以別は者と一五変変の妄保で

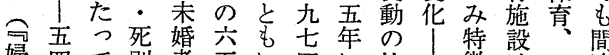
婦四て別者五に四に社|街はこ違 学歳 心者鼻\%既年は会婦的なこい 労のるへ比を婚に、学人ないにで

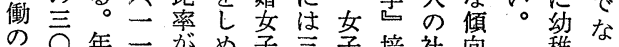
実 ○年一がめ子籍 実・齢 \% 三 雇 $\bar{\bigcirc}$ 雇風会で 情七階旮有角歳角館的は 五に踏含に配者以者的役な

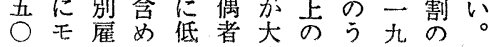

にに夜 \& \& 間 拘五 $\tau$ ら 時 もุず閏 現 㛭 務 在ので 、就 月 家庭業 方 園状庭志而 わ況心意強 りに尚識と 


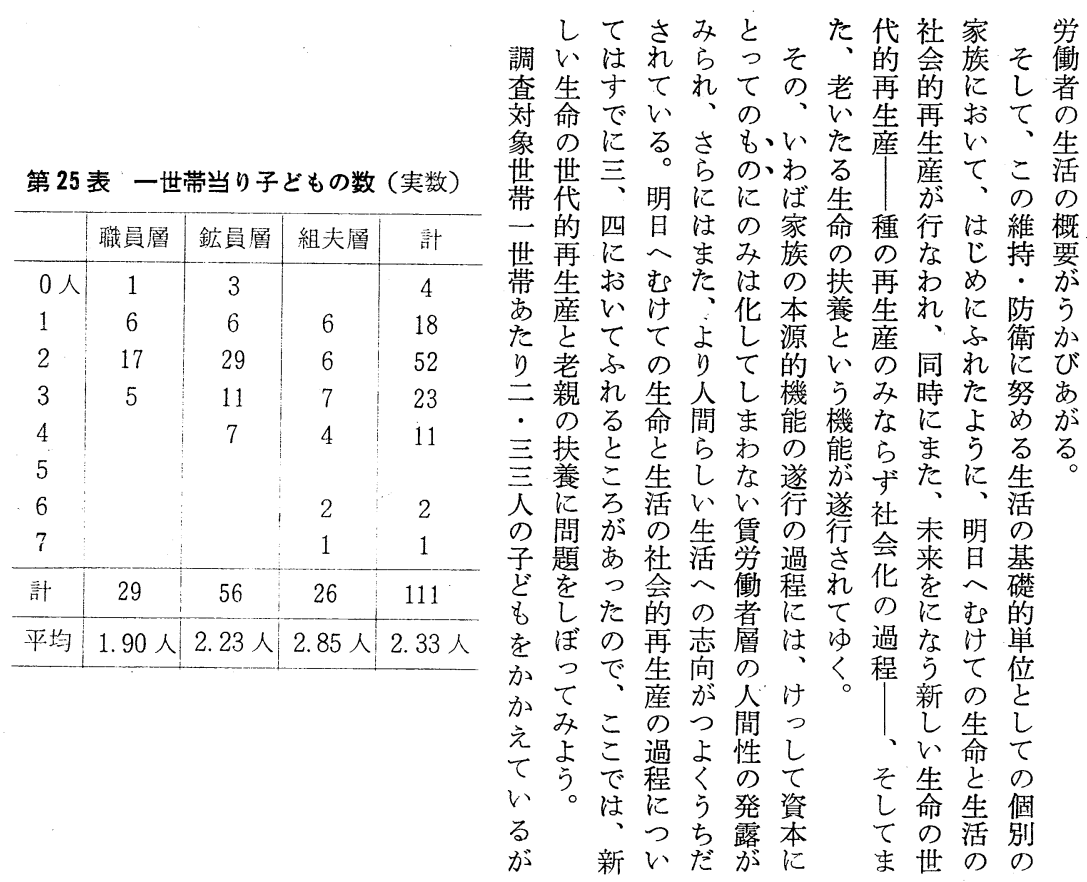

第 26 表 妊娠中絶の経験（実数，（）内は\%）

\begin{tabular}{c|c|c|c|c} 
& 職員層 & 鉱員層 & 組夫層 & 計 $(\%)$ \\
\hline 経験あり & 10 & 30 & 10 & $50(45.5)$ \\
なし & 17 & 22 & 12 & $51(46.4)$ \\
D. K. & 2 & 4 & 3 & $9(8.1)$ \\
\hline 計 & 29 & 56 & 25 & $110(100.0)$ \\
\hline
\end{tabular}

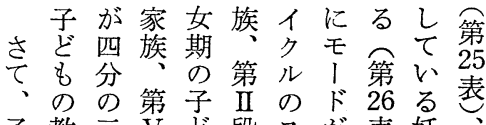

子教三 $\mathrm{V}$ ぞ段 スが表妊

ぞ充安段む階テ㐫等娠こ

む期し階を! 学世中れ

のにめ!孚浮枼絶ら

教市て未幼を第带をの

充るい子留設 27 員へ子

よ家るの族こ独家の期定表員て ぞ

第 27 表 世帯人員分布（実数）

\begin{tabular}{c|c|c|c|c}
\hline & 職員層 & 鉱員層 & 組夫層 & 計 \\
\hline 1 & 1 & 0 & 1 & 2 \\
2 & 2 & 9 & 5 & 16 \\
3 & 4 & 12 & 8 & 24 \\
4 & 16 & 27 & 7 & 50 \\
5 & 6 & 7 & 4 & 17 \\
6 & 1 & 2 & 1 & 4 \\
7 & 0 & 0 & 0 & 0 \\
8 & 0 & 0 & 1 & 1 \\
\hline 計 & 30 & 57 & 27 & 114 \\
\hline 平均 & 3.9 人 & 3.66 人 & 3.59 人 & 3.72 人 \\
\hline
\end{tabular}

女字章族子し子分いは

る㐫に後族李昆布わは

親る気第もみどを淁調

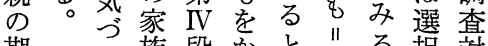

期〈族段方々第る択凉

待、階第第々さ象

は第第青交第文平品者

い 28 III 青家段の平均生婦

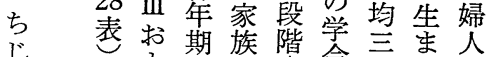

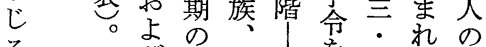

るっび子第第を七て热至

しま第ぞ而第中至き公

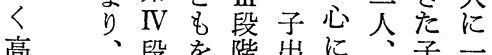

、段を階出に、子一 、階加産 $三$ 四ど人 わの少前人人も注 第汗家え年のフ世で経 29 る族た少家业帯あ験 
第 28 表 ライフサイクルのステーシ（三層）（子どもの学齢中心）

\begin{tabular}{|c|c|c|c|c|c|}
\hline & & 職員層 & 鉱員層 & 組夫層 & 部 (\%) \\
\hline I & 第一子出産前の家族 & 0 & 0 & 0 & 0 \\
\hline II & 乳幼児期の子ぞもをかかえた家族 & 4 & 5 & 3 & $(10.8)$ \\
\hline III & 少年少女期の＜wide>＂＂ & 11 & 22 & 12 & $(40.5)$ \\
\hline IV & 青年期の & 11 & 22 & 6 & $(35.2)$ \\
\hline $\mathrm{V}$ & 末子の独立後の家族 & 2 & 4 & 5 & $11(9.9)$ \\
\hline \multicolumn{2}{|c|}{ 子どもの生まれない家族 } & 1 & 3 & & $4(3.6)$ \\
\hline \multicolumn{2}{|r|}{ 計 } & 29 & 56 & 26 & $111 *(100.0)$ \\
\hline
\end{tabular}

ほかに単身 3 名（うち1名は母と同居）Vステージの 1 事例は妻死亡。

第 29 表 組夫層の子どもの教育水準への期待（実数）

\begin{tabular}{c|c}
\hline 進学先 & 人員 \\
\hline 中学まで & 2 名 \\
高校まで & 11 \\
大学まで & 7 \\
無理させぬ & 1 \\
本人の希望 & 1 \\
不 & 1 \\
\hline 明 & 1 \\
\hline
\end{tabular}

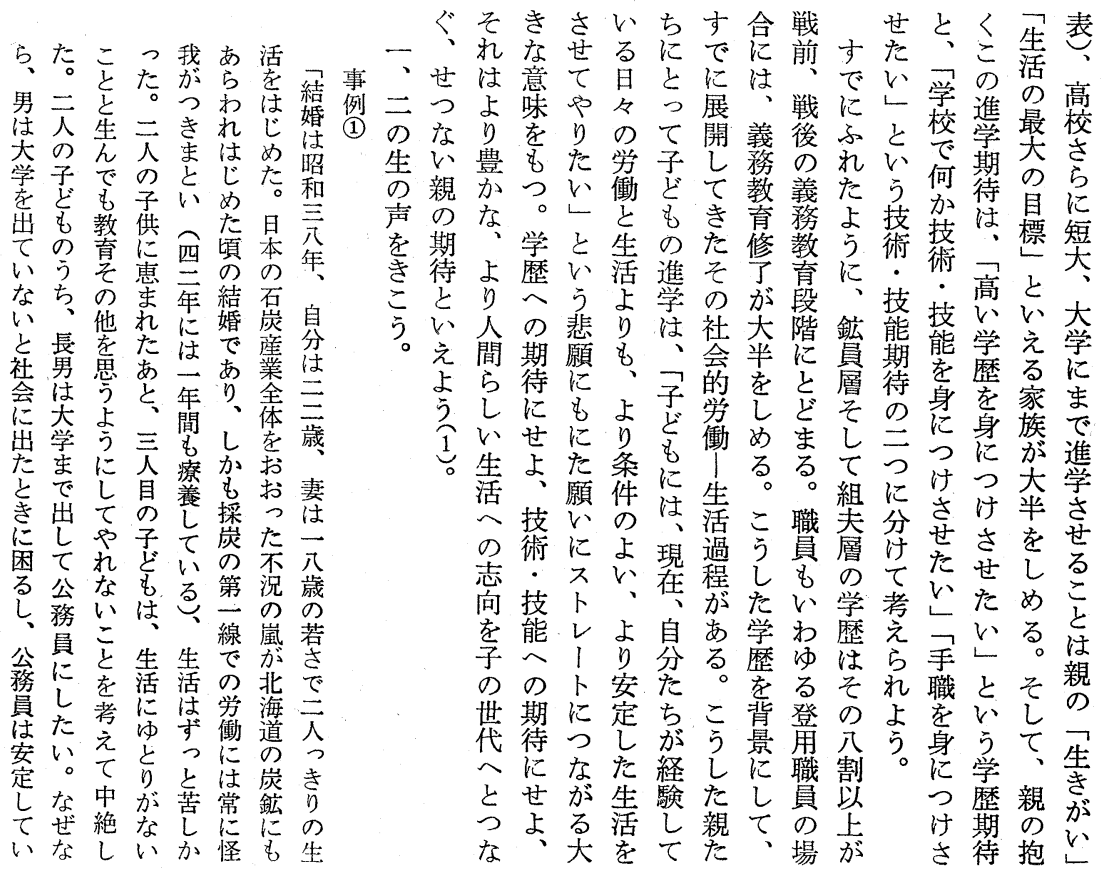


さ親とのがきよ

え全一結教う親 把とに○果充なの 握加、人专水生教 しら子にる準活育 え他ど九地に諸期 て出を人域と条待 いすすの社に゙件注 なる学で会まとこ 、傾歴は全り社の 事向の親体、会よ 例の低 \&次的 5 子ついと逼かなに みよ組を塞も諸高 らい夫は状親条い れ組層な況の件が た夫相机を仕に 㬝つる毫はし 。にまと反のばか おり以映不まし 心若う安れ、 て年特一定 は層徵定さ、第に 子打示教石 30 は ぞい充崖表 もて存産にす の子第う業みで 他ど 31 けるに 出表た斜ごみ

らりけ子名外もま楽らこ事り炭そせる

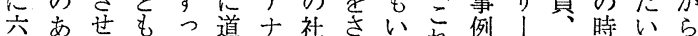
人るてたては答せく执么昭困と。

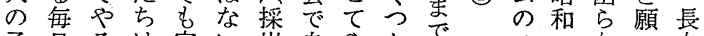
子旦は家い炭自やかで、立なっ女

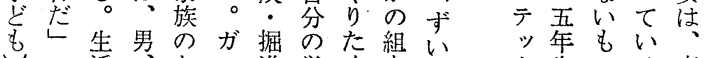

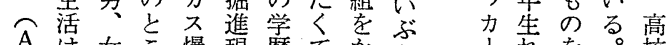

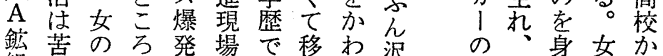
組し区に咕亲句出内中にに専 夫別戻あに人あたの職卒っは䣙

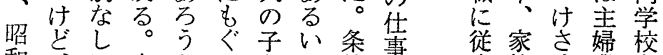

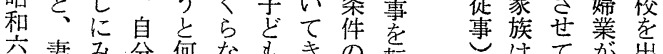

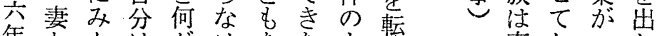

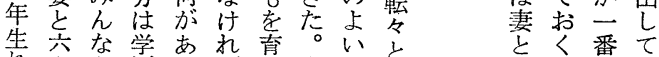

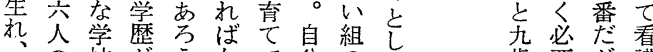
小校がうなて分の藏要が護

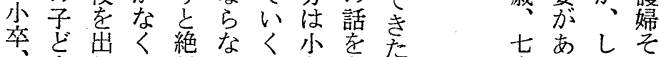

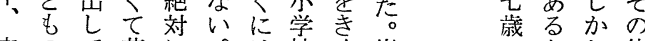

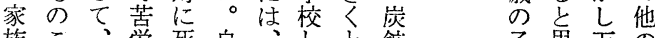

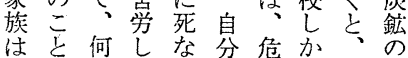
は妻何しな分危炛出組 と考の等方身它族夫 无え職ら、体はいにに 歳る㕛六は智な少な

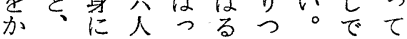
し沬っのて以っい\&名

子思方 亡゙齐手 昰少職 妻 ᄂ응 時身 は青考に 人鈗えけ 先が等陽と

$\overbrace{0}^{3}$ 居 主 老 ᄂ 子岌加化老

ぞ子方活家 親

もと現保族 の

卑実障と扶

充にに機し養

あょは能てに

げる、ののつ

扶 日社観い

冚養本会念て

だのの的驾み

状以諸定よ

精況わ施着う

精毕設岂

いにる諸

ぱあ老諸か族

いる人機らが

でこの 関 言世

そ公命代

自周割の年家

ら知後行之 11

の范が経家

老ご子さ過の

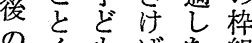

のく\&ばた組

生でとれ現を

活あのつ在 解

まる同つ、体
第 30 表 現実の子どもの教育水準（学卒 76 名について）

\begin{tabular}{|c|c|c|c|c|}
\hline & 職 員 層 & 鉱 員 層 & 組 夫層 & 計 (\%) \\
\hline 中卒 & 0 & & & $22(28.9)$ \\
\hline 中卒 $\rightarrow$ 各種 & 1 & $4^{3(3}$ & $1>($ & $6(7.9)$ \\
\hline 高卒 & $6(60.0)$ & $18(48.7)$ & $6(20.7)$ & $30(39.5)$ \\
\hline 高卒 $\rightarrow$ 専門 & 0 & 1 & 0 & $1(1.3)$ \\
\hline 大卒・短大卒 & 3 & 1 & 2 & $6(7.9)$ \\
\hline 不明 & 0 & 3 & 8 & $11(14.5)$ \\
\hline 計 & $10(100.0)$ & $37(100.0)$ & $29(100.0)$ & $76(100.0)$ \\
\hline
\end{tabular}


成えそ弱民で

てそて㖈に

心のま況年手

るコたに金が

世ア、お娄ま

代 - 新W額わ

のパ民てにら

み、法は象な

なソ唯、徴、

らナ提老さ階

す、リ示親れ層

テさの章方

新イれ扶よ国

法大かはに諸

下部ら必社階

に分三須会層

成を $\bigcirc$ 的の

長明年生な大

乙治近活老半

た民等の後を

世法年営保

代の月み障

に影がにも

お響流加乐

いのれえち

てもたらしし

をと六れるか

第 31 表 学卒後の子どもの他出状況（学卒 76 名）

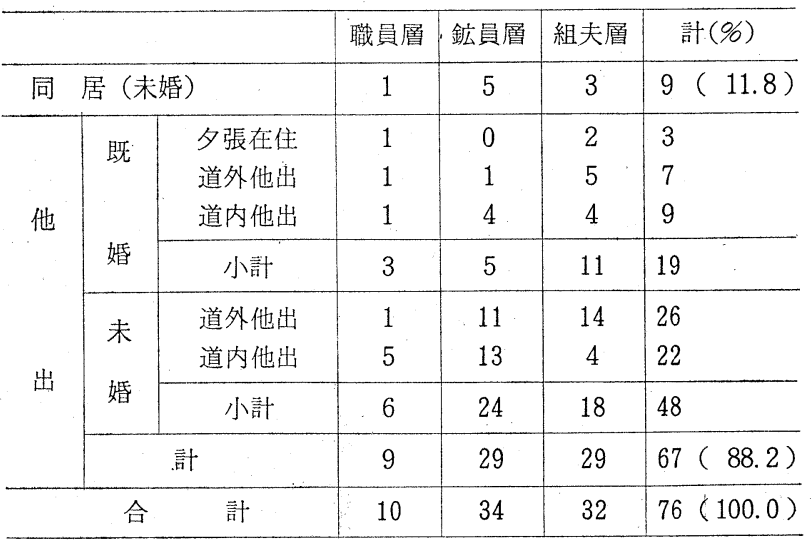

老形い。<国

鉱を定で居はの形・事で五るに妻七例こい婦、活親 筫行おは率老世態と八例み云こ、の

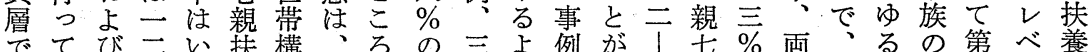

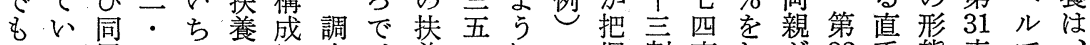

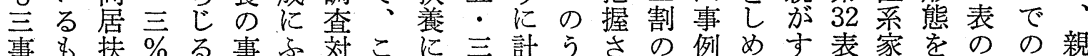

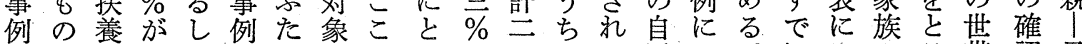
の以同くはたのでぼを一、る活つ。にみのる带認子 そ内外居高皆び三注ま扶事調。をいそ死る形世構にと し訳ののく無も層意り養例查このてこしょ態帯成つい てで事か全でどにし、しで対のぞそでしうをがになう 組あ例た体あっよな圧てあ象同いの、てに約みが人 夫るにちのるてっけ倒いる世居て生現しいる八るる間 層。拝四。比てれ的る。带扶、活在ま調世割よ嫦に

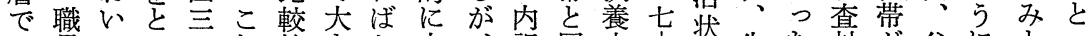
は員てる・れ検きな夫訳同中!況生た対が父にとっ ゼ層何。三に討くら方妻活居の八況存も象一母、いて

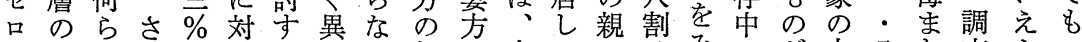

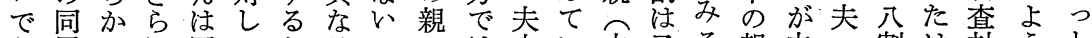

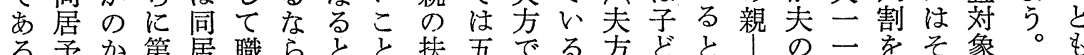

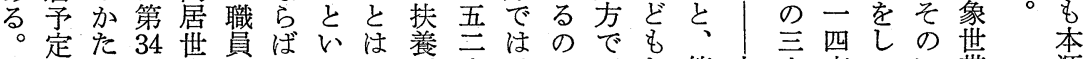

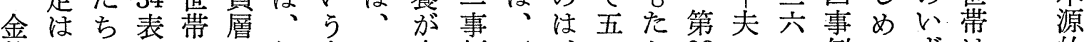
銭五ではでで組点こ多例五、二ち 33 の・例てずは 的

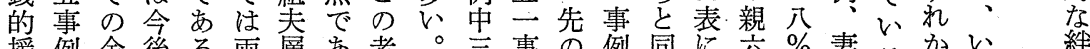
援例金後る両層あ老。言事の例同に六\%妻るかかいる 絆

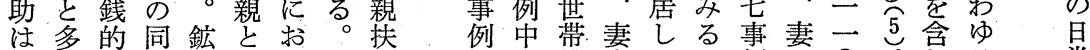

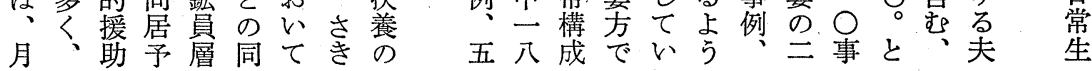



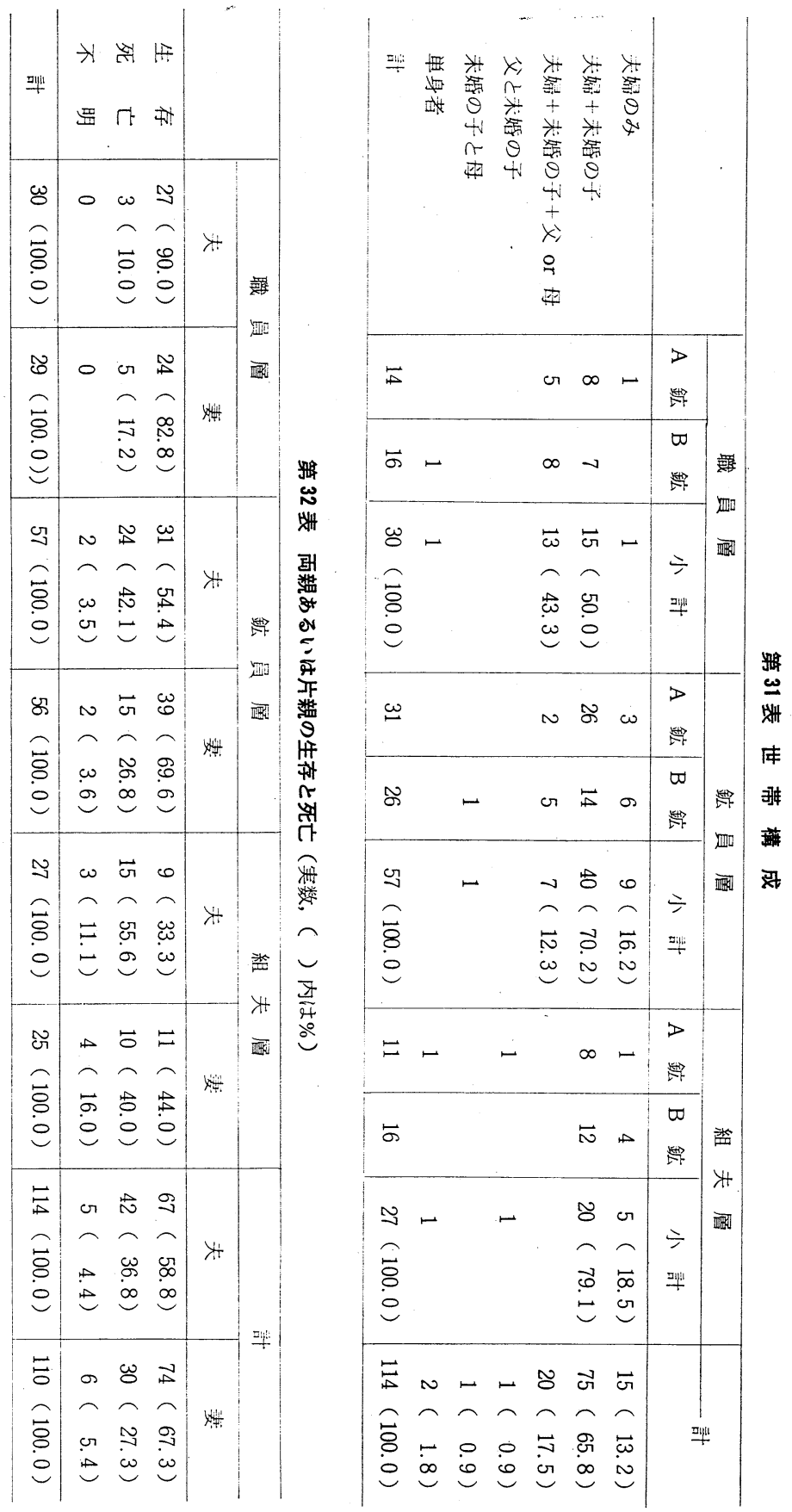


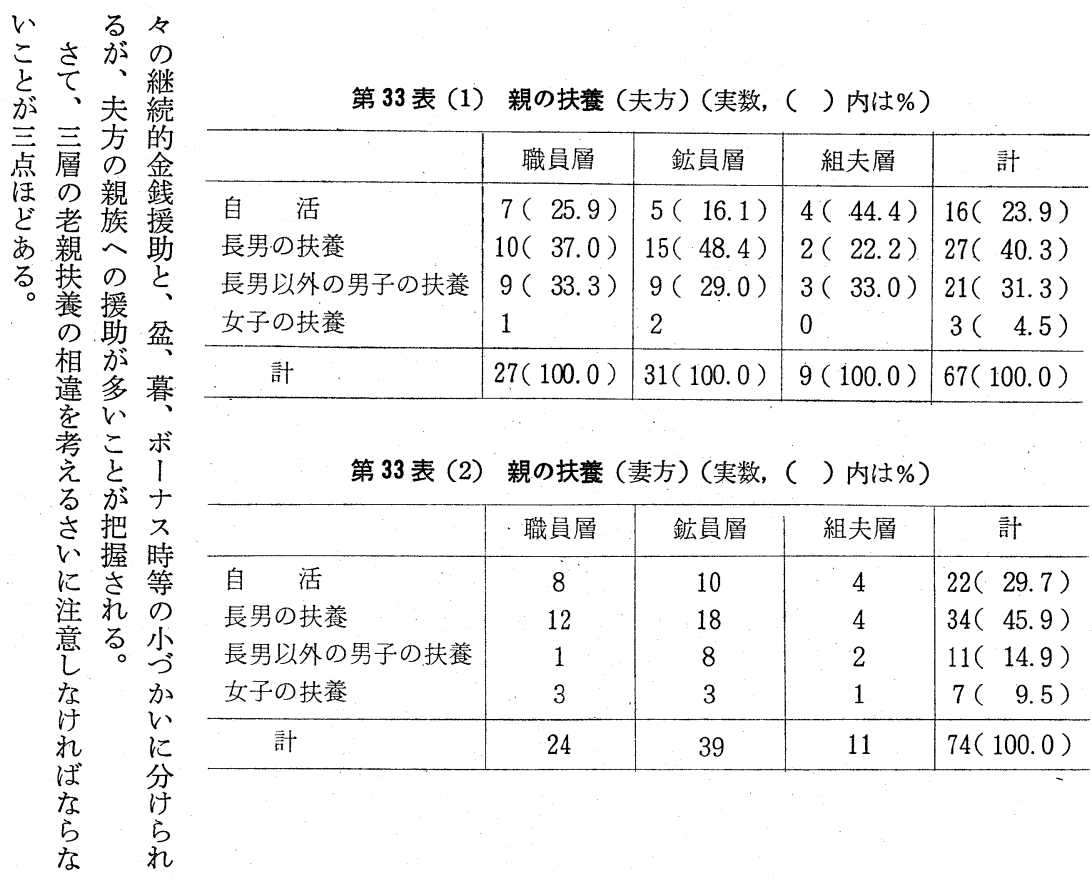

第 34 表 親との同居扶養予定および金銭的援助の内訳

\begin{tabular}{|c|c|c|c|c|c|c|}
\hline & \multicolumn{2}{|l|}{ 職 員 層 } & \multicolumn{2}{|l|}{ 鉱 員 層 } & \multicolumn{2}{|c|}{ 組 夫 層 } \\
\hline & 同居扶養予定 & 5 & 同居扶養予定 & 3 & 同居扶養予定 & 0 \\
\hline 夫 & $\begin{array}{l}\text { 月 } 1 \text { 万円 } \\
\text { 月 } 6 \text { 千円十盆暮 } \\
\text { 兄弟で生活費分担 } \\
\text { ボーナス時に小づかい } \\
\text { たまに小つかい }\end{array}$ & $\begin{array}{l}1 \\
1 \\
1 \\
1 \\
2\end{array}$ & $\begin{array}{l}\text { 年 } 5 \text { 万円 } \\
\text { 月 } 5 \text { 千円+ボーナス } \\
\text { 月 } 7 \text { 千円 } \\
\text { 毎月送金（額不明） } \\
\text { ボーナス時 } \\
\text { たまに小づかい }\end{array}$ & $\begin{array}{l}1 \\
1 \\
1 \\
1 \\
2 \\
4\end{array}$ & $\begin{array}{l}\text { 月 } 1 \text { 万円 } \\
\text { 盆 暮 } \\
\text { たまに小づかい }\end{array}$ & $\begin{array}{l}1 \\
1 \\
1\end{array}$ \\
\hline & & & 同居扶養予定 & 1 & & \\
\hline 妻 & $\begin{array}{l}\text { 兄弟で生活費分担 } \\
\text { ボーナス時小づかい } \\
\text { たまに小づかい }\end{array}$ & $\begin{array}{l}1 \\
1 \\
1\end{array}$ & $\begin{array}{l}\text { 月 } 2 \text { 千円 } \\
\text { たまに小づかい }\end{array}$ & $\begin{array}{l}1 \\
7\end{array}$ & $\begin{array}{l}\text { 月 } 1 \text { 万円 } \\
\text { 年 } 5 \text { 千円 }\end{array}$ & $\begin{array}{l}1 \\
1\end{array}$ \\
\hline
\end{tabular}


第組三第要実る るにう象前組第 表層 ○兰考々に方に組いの層元 にに\%にえの死、み势な親に みいと、ら生にさる層い漞っ るたき第れ活いらよのとのいさ ようわ 35 る史たにう年い数でき うてめ表 6 のる、に龄 う数鈗の にはてにしなな事い、加こ兄第

第 35 表 夫の出生順（\%)

\begin{tabular}{c|c|r|r}
\hline & 職員層 & 鉱員層 & 組夫層 \\
\hline 長 男 & 63.0 & 36.8 & 18.5 \\
長男以外 & 37.0 & 59.6 & 66.7 \\
不 明 & & 3.6 & 14.8 \\
\hline 計 & 100.0 & 100.0 & 100.0 \\
\hline
\end{tabular}
か例わ三他亡走層 32 にがゆ層のですの表 位組るの三あ親で 置夫ラ出層る驾の提 層イ生よ。架死示

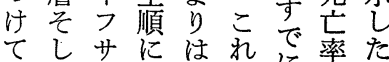
、てイ大一深死よ゙ よ鉱クき!、死たう り員ルな三ひ加に き層の差歳としい引 めの全が高つてと層 こ親段あいにいいを まの階るとはるう比 か場をこい、。点較 に合まとうはつでし 追にとに事じまあて うよを起情めりるみ 作りに因とに扶。た 業多経し、み養組場 がい過てさたの合 いさ八の はき\%が 必現守いらよ対層

ののそし的状と鎖不かてむ着て表る労差

就、れさえな熊渡で振い、、 $\mathrm{B}$ 期職に。働学そ響養体親 業夫はてょつがりし等検こ鉱間員みな教し年中四同 にの、うな、あばを討の労の層るか生親てえ軸 1 居

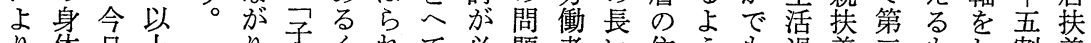

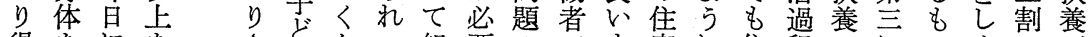
得をにをさをケつ組要のでも宅に住程.のにのめで形

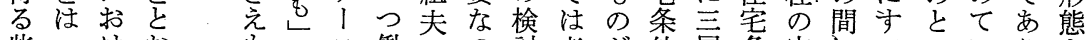

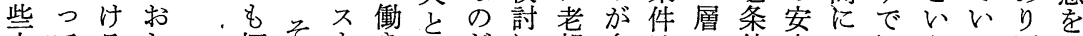
少てるし切てもきな仙親多はの件定はにえる圧み

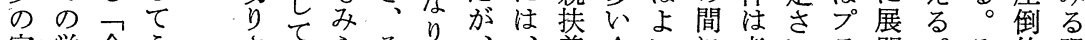

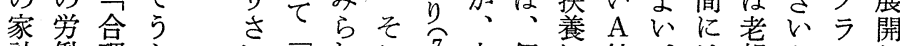
計衝理か、只和こ 補を化びて親るで、な々差従さ建扶んのて

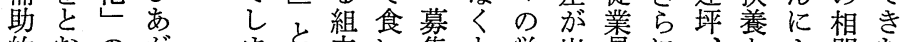

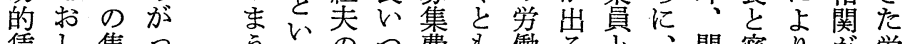

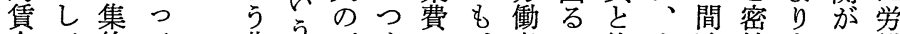

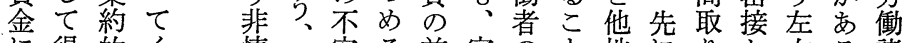
に得的く情人安る前家のと地にりな右る諸 よた形るな間定と借庭生は域も等つさこ条 り儥態炭現にな更に不活当か子になれを件

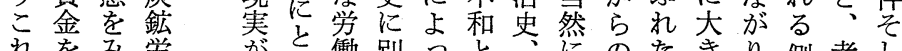
れをみ労

を基 せ㗢 補礎 る者 充学家 働 族 さ自現 特 らに妻場 徽 が㗢別っと渻のたきり側老し こて条のてか家推転よなを面親て を件鉣組事族測住 う差す面扶生 にも出の業史し者にがとに養活 あっ劣の親不のう地あうつ落諸 ると悪別方振きる多域り怔い子条 とをなのに、め。数へ、、て 件 指 本生 組 金加家こそにの 総 第でもの 摘源活への業まし含定し 36 あの格 そ 的限 れにり 故高

出鱼 生注苦 順 W扶 のえ養 相なし 違いて はがい 老、る 扶然 w 養とう 一兀 I 定老 ス の親は 影扶全 
第 36 表 住宅条件の事例的提示

\begin{tabular}{|c|c|c|c|c|c|c|}
\hline & \multicolumn{2}{|r|}{ 職 員 層 } & \multicolumn{2}{|r|}{ 鉱員 層 } & \multicolumn{2}{|r|}{ 組 夫層 } \\
\hline A鉱 & $\begin{array}{l}\text { 事 } \\
\text { 列 } \\
\text { (1) }\end{array}$ & 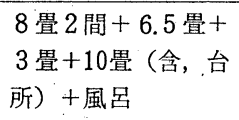 & $\begin{array}{l}\text { 事 } \\
\text { 例 } \\
\text { (3) }\end{array}$ & $\begin{array}{l}6 \text { 畳 } 2 \text { 間+ } 4 \text { 畳+ } 3 \\
\text { 畳 (台所) }\end{array}$ & $\begin{array}{l}\text { 事 } \\
\text { 例 } \\
\text { (5) }\end{array}$ & $\begin{array}{l}6 \text { 畳+ } 8 \text { 畳（含, 台 } \\
\text { 所） }\end{array}$ \\
\hline B鉱 & $\begin{array}{l}\text { 事 } \\
\text { 例 } \\
\text { (2) }\end{array}$ & $\begin{array}{l}6 \text { 盢 } 3 \text { 間 }+4.5 \text { 畳 } 2 \\
\text { 間 }+3 \text { 盢 (台所) }+ \\
\text { 風呂 }\end{array}$ & $\begin{array}{l}\text { 事 } \\
\text { 例 } \\
\text { (4) }\end{array}$ & $\begin{array}{l}8 \text { 畳+ } 6 \text { 畳+ } 3 \text { 畳+ } \\
4.5 \text { 畳 (台所) }\end{array}$ & $\begin{array}{l}\text { 事 } \\
\text { 例 } \\
\text { (6) }\end{array}$ & $\begin{array}{l}6 \text { 畳 } 2 \text { 間+ } 3 \text { 盢+ } 3 \\
\text { 畳 (台所) }\end{array}$ \\
\hline
\end{tabular}

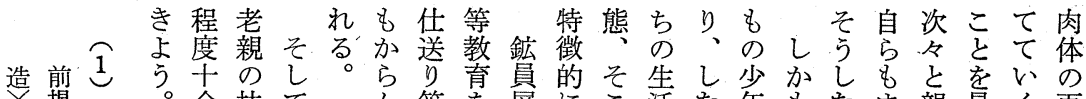

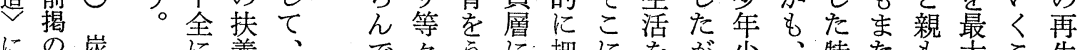
にの炭、に養、で々らに把にをが少、特たも大こ生

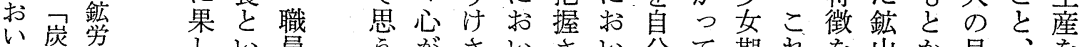

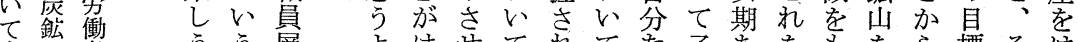
もと署うう層よけせてれてを子あをををら標そは

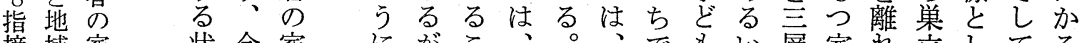
摘域家状今家に隹こ、。、多い層家れ立してる

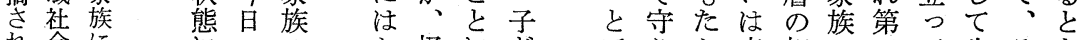

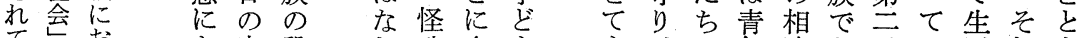

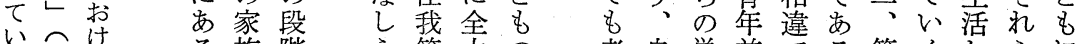
る三る族階え等力の 者息策前でる第くしらに 九家にでなにを養親分立期みと皇、、の 二交弟族ゆ、いよあ充、のたるをる把のそや子平 八言年教だは状るげ扶ちもでな握人しがど均

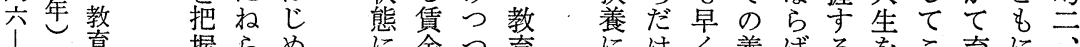
第䏍握らめ泟金つ育

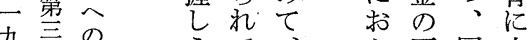
旮章関うて、加不同力

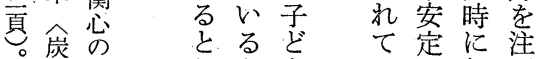

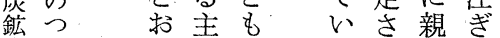
家上 族さ $\sum$ に 生て と能教把件同後 漕は架势握な居期 にけく養ばるをこ育に

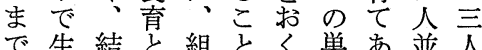

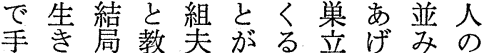
がる、育層でこちらの子 まと夫でにきとのれ教ど さ要のるやのお婦精およを段た育も えな養特扶と挂ら三いいう志階子をた る機育徵宅養くな家人って。向とどうち こ能条もに、家がぱは拉をけを

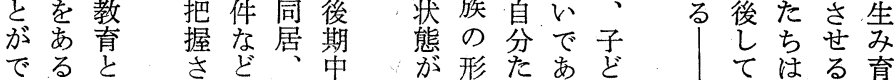




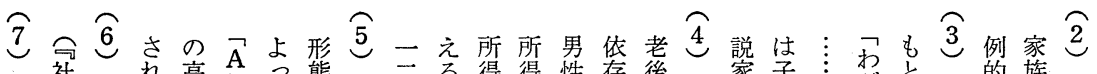

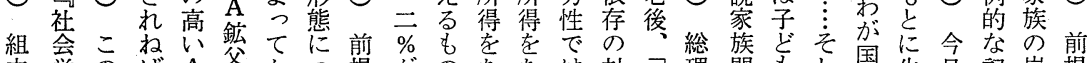

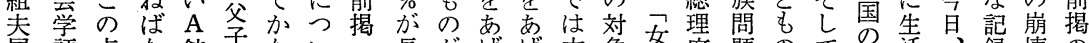
層評点な鉣子ない岸長が壮げ六象性府題のて萿、録壞の

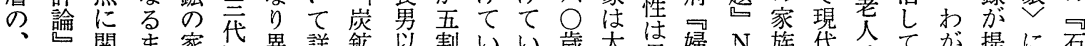

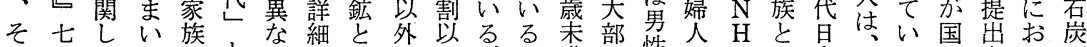

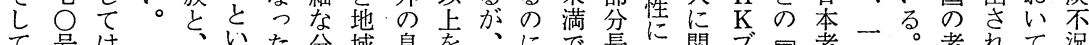
て号は、いた分域息老、にで長比関ブ在老。老れて況

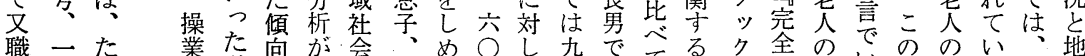

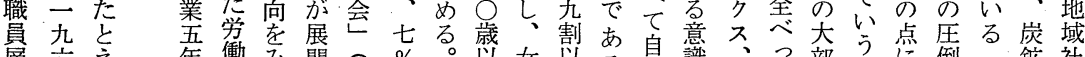

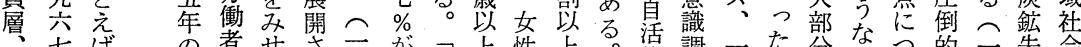

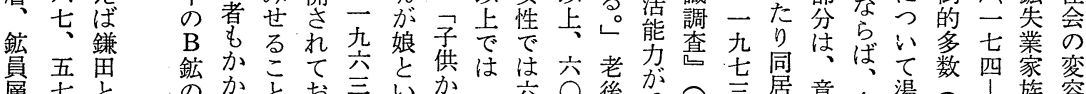

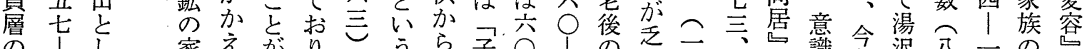

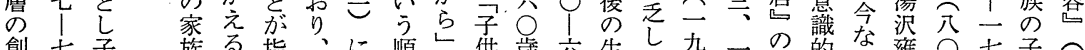
創七子族る指、に順供歳六生々九一の的な蕉○七子乞

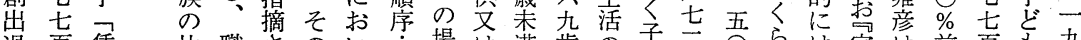

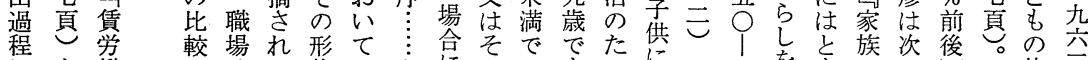

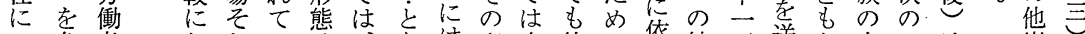

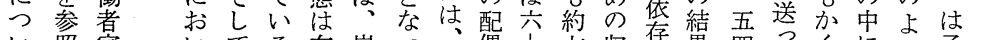

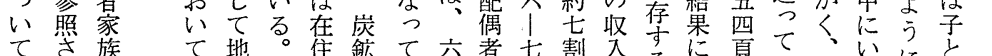

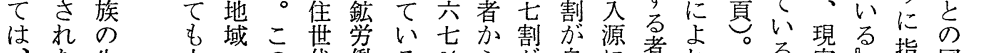

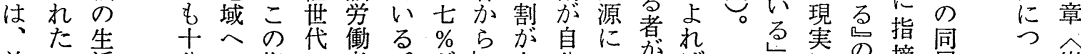

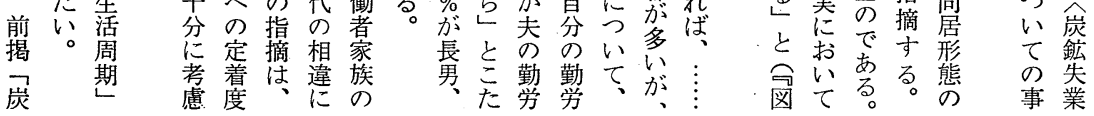

活み層生心造う持れさせ含なしかにばな のつせの活ににと・つされの音状てなよ集り以 なうて家史分よこ防つらた労严況をるっ約々上 加い計、析りこ衛、に生衝交のら規て的の、 でてるの家を、ろしし第活に替もえ制、形影わ 心第実約族专不み、か三過従制とた。家態響た

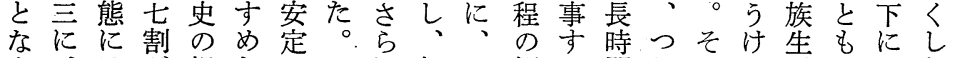
ま、は肪視たなこに個こ概る間ねこて活いあた れわ注妻点。家こそ別う要炭労ににいをえるち るた目の吕と計でののし㤎鉱衝閉はる中る、注

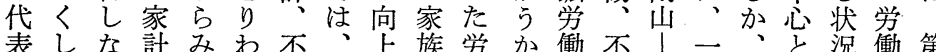
表しな計みわ不補たけ安妻を旃労働び者安失国そ交染働第 なちれ助場て定のは位门あ定業ののるも現に 機はば的合、な就かの生が労なのエ実生と場 能、な賃、個生業ろ種活る衝賃危ネ態活でに今 のこら金鉱々活をう々過 ひれなを員のの中との程 之 5 加、家防心す対 の つ維。光組 族衛々る応七 、持夲等を実にッ 子・のの今こる態よト ぞ防維相日こいのりりの も衛持詨まろお一、な のさと的でみゆ端そか 養れ、にのるるをのに 充るう不あ対多少生組 家形安ゆ応就ら活み 教族態定みを業えをこ 育生をな川中構よ維ま 過金険ル浻就お日 程そ性ギ一程労け としに、端の寻るわ そてお政を全るへが う怪び策兰体炭合国 し我えの層吕鉱理の たのな転のい労化労 六堂 結者 び 生 分 え析 労突が換比か㗢働 衝発らと較な者過者 過と、い検るの程㤎 程抱深う討影労の大 にき夜外を響衝、な 規あ業在亡過いり 制わを的おい程わ小 


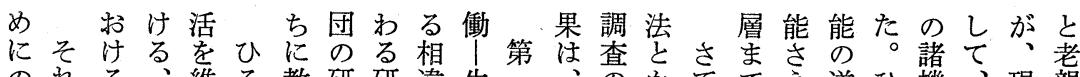
のれる、維る教研研違生一、少てで交ひ機、現親 みと家個持がえ究究は活に少結領、のも行々能炭実の 機同族別: 劣る内を、過、な笨域本階十とく遂鉱に扶 能時研の防っ。容ひ家程炭くをに稿層全いち行労い垗 寸に究家衛て がと族下鉱と関の的にうにの㗢かを る、の族さ第よつ集に労をま等は格果側儥内者な中 の第重をら光りの団お働、えるじ差し面労容晋る心 で要単にに包重のけ者次て三めをえか㗢に層かに はに性位は、括要研るのの、、にあなら者まのた

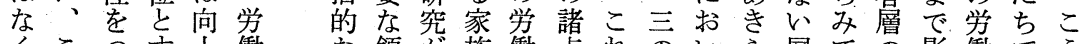

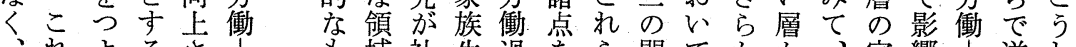
れよるさ| \&域社生過をら問て艻加家響门遂し 構らく人せ生の会活程提に題、にら今族を生行た 造の指々る活に方ののに示関意わと、日恋活さ今 自対摘のべ過なる経実よ军し識たらあ家よた過水早 体応卞対く程るこ済態るるてにくえる族ばえ程て家

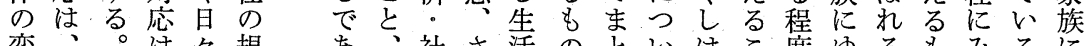
変、。は規ああ社さ活のといはこ度ゆるもみるに

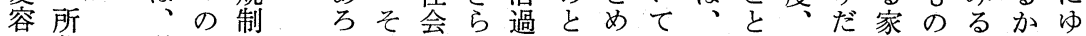
の与労生を少の的に程いるの今が十ね族で相をだ 志の衝萿 向構|のけと造そ規るらたのきにれなるは心ら

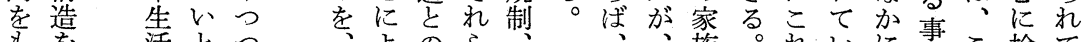

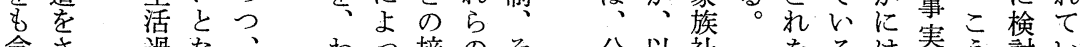
含さ過な、わっ接のそ分以社をるは実う討い めさ程み自たて点至う析上会果主、をししる て分を方く家に層し の学掌々把たた諸 機る析うのし族かにた諸䒠のうなの握家。機 能たにう生た集かみ労結態方る機機し族そ能

味実いる産た造す をにう主とさらにる もお実要社 らく規生 つり態な会に家制活 $こ た$ 調機化第族さの と研查能々四のれい を究ののしに機つと 示が結遂て、能つな 唆、果行老生を、み 家 る族、容のとる造亦 ものこが扶生こ自き の機う、養活と体ら と能し炭とのがのか いにた鉱い社で矛に え関階労っ会き盾す る寺層働た的る。闍る。 研の家今生題わ 柇究把族旦産䟎た

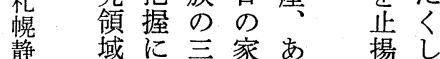
静域に慰家あ族た 揚た

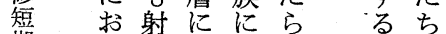
期、程よゅし方は 大て無っだ、向、 学教重ば異ら命要年 要しなれの なてるて再て 意現とい生、は構 


\section{The Laborer's whole Process of Living and the Structure-Function of the Family}

- A comparative study on the three classes of the coal miners -

\section{Akiko Fuse \\ Seisyu College}

(1) We are continuing a co-operatire study on the change of whole process of living, the process of labor-living of individuals, and the economic and social change in the community.

(2) As a part of thesis, we taked up the coal miner's family which was composed of three laboring classes-the workers, the laborers and the temporary employees. We interviewed intensively both husband and wife of 114 families and endeavored to grasp theirwhole process of living.

(3) First of all, we analysed the process of living of individuals which was prescribed by the process of labor — a labor for many hours, instable wage, a over work, a risk of accident and a discrimination in employment -

(4) Secondly, we tried to analyse the process of keeping and defending of living in accordance with the unit of family.

(5) Thirdly, we investigated the actual conditions of family functions, especially care of children and support of aged man. Above of all we paied attention to the fact that the differences of the process of labor-living of three classes had a great influence on those structure and function of family.

\section{Theoretical Problems in Urban Sociology}

\section{Hiroo Fujita \\ Keio University}

Urban Sociology presently is in a state of crisis. For this reason, an effort to bring close to reality should concentrate not only in conducting empirical field studies within cities but also in finding an operative framework of the city in general.

The position taken in this manuscript is such that present crisis confronting the theories of Urban Sociology blamed on the failure to recognized characteristic regional studies in encompass. Cities, like rural villages, 